\title{
Zootherapy as a Potential Pathway for Zoonotic Spillover: a Mixed-methods Study of the Use of Animal Products in Medicinal and Cultural Practices in Nigeria
}

\section{Sagan Friant ( $\nabla$ sagan.friant@psu.edu )}

The Pennsylvania State University https://orcid.org/0000-0003-1664-5180

Jesse Bonwitt

Centers for Disease Control and Prevention

Wilfred A Ayambem

University of Calabar

Nzube M Ifebueme

University of Calabar

Alobi 0 Alobi

University of Calabar

Oshama M Otukpa

University of Calabar

Andrew J Bennett

Naval Medical Research Center

Corrigan Shea

University of Wisconsin-Madison

Jessica M Rothman

Hunter College of the City University of New York

Tony L Goldberg

University of Wisconsin-Madison

Jerry K Jacka

University of Colorado Boulder

\section{Research}

Keywords: Zoonoses, risk behavior, human-animal interactions, traditional medicine, ethnomedicine, ethnoepidemiology, wildlife

Posted Date: May 25th, 2021 
DOl: https://doi.org/10.21203/rs.3.rs-536227/v1

License: (c) (1) This work is licensed under a Creative Commons Attribution 4.0 International License. Read Full License

Version of Record: A version of this preprint was published at One Health Outlook on February 26th, 2022. See the published version at https://doi.org/10.1186/s42522-022-00060-3. 


\section{Abstract}

Background: Understanding how and why people interact with animals is important for prevention and control of zoonoses. To date, studies have primarily focused on the most visible forms of human-animal contact (e.g., hunting and consumption), thereby blinding One Health researchers and practitioners to the broad range of human-animal interactions that can serve as neglected sources of zoonotic diseases. Zootherapy, the use of animal products for traditional medicine and cultural practices, is widespread and can generate opportunities for human exposure to zoonoses. Still, existing research examining zootherapies omits details necessary to adequately assess potential zoonotic risks.

Methods: We used a mixed-methods approach, combining quantitative and qualitative data from questionnaires, key informant interviews, and field notes to examine the use of zootherapy in nine villages engaged in wildlife hunting, consumption, and trade in Nigeria. We analyzed medicinal and cultural practices involving animals from a zoonotic disease perspective, by including details of animal use that may generate pathways for transmission of animal-borne infections. We also examined the sociodemographic and cultural contexts of zootherapeutic practices that can further shape the nature and frequency of human-animal interactions.

Results: Within our study population, people reported using 44 different animal species for zootherapeutic practices, including "high risk" taxonomic groups. Variation in use of animal parts, preparation norms, and administration practices generated a highly diverse set of zootherapeutic practices $(n=292)$ and variation in associated zoonotic exposure risks. Use of zootherapy was patterned by demographic and environmental contexts, with zootherapy more commonly practiced by hunting households $(\mathrm{OR}=2.47, \mathrm{p}<0.01)$, and prescriptions that were gender and age specific (e.g., maternal or pediatric care) or highly seasonal (e.g., associated with annual festivals and seasonal illnesses). Specific practices were informed by different theories of healing (i.e., "like cures like" theory of healing and sympathetic healing and magic) that further shaped the nature of human-animal interactions via zootherapy.

Conclusions: Epidemiological investigations of zoonoses and public health interventions that aim to reduce zoonotic exposures should explicitly consider zootherapy as a potential pathway for disease transmission and consider the sociocultural contexts of their use in health messaging and interventions.

\section{Background}

Human-animal interactions through animal husbandry, hunting, and butchering of wildlife are frequentlycited causes of zoonotic disease transmission and emergence in human populations [1, 2]. However, harvesting and preparing meat for consumption are among many activities that bring humans, wildlife, and their bodily fluids in close contact [3]. Zootherapy, the use of animals for traditional medicine and related cultural purposes (e.g., healing, witchcraft, rituals, charms, ceremonies, and festivals), involves medicinal and symbolic use of animals and animal by-products (e.g., excreta, fur, feather, bones, glands, 
etc.). Zootherapy may therefore expose people to animals and their zoonotic agents. However, studies of zootherapies have predominantly analyzed these practices from ethnomedical and conservation perspectives attending to the species used and their medical purpose [4-8], with minimal attention to animal handling and associated potential zoonotic risks [9-12]. Although cultural practices involving wild animals are well recognized as potential transmission routes for zoonoses [5, 9-11, 13, 14], efforts to understand the full extent of these practices have lagged behind more visible forms of human-animal contact (e.g. hunting and consumption).

The potential public health benefits of traditional medicine (usually therapeutic plants, but also minerals and animals) have been widely discussed $[10,65,66]$. Traditional medicine is often the only source of medical care for a great proportion of the population in the developing world, offering communitycentered holistic approach to health and healing that is more accessible, acceptable, and affordable [6770]. For example, traditional medicine plays a significant role in meeting the health care needs of the majority of the Nigerian population, with an estimated $75-80 \%$ of people using the services of traditional healers [71]. Comparatively little attention has been given to public health risks introduced from traditional medicine, specifically, zoonotic exposure risks from handling animals for medicine and other cultural practices.

Rodents, bats, and primates consistently stand out as important wildlife reservoirs of zoonotic diseases [15-20], and these taxa feature prominently in zootherapy worldwide $[4,21,22]$. Rodents host the vast majority of mammal-borne zoonotic viruses [18, 23], and appear in zootherapies globally [8, 11, 31-33]. In a survey of 22 traditional medicine markets across Benin, rodents were the most abundant and speciose taxa represented, with nearly half of the reported local species found in traditional medicine markets [27]. Preparation and use of rodents as traditional medicine could provide less apparent opportunities for the transmission of rodent-borne zoonoses. For example, arenaviruses (e.g., Lassa virus, Lujo virus, and lymphocytic choriomeningitis virus), hantaviruses, orthopoxviruses (e.g., vaccinia, cowpox, and monkeypox viruses), and causative agents of bacterial diseases (e.g., plague, leptospirosis, rat bite fever, salmonella, and tularemia) are transmitted from rodents through often unidentified routes [28]. Understanding the potential risks associated with use of rodents and other animals for zootherapy requires an improved understanding of how potential hosts are handled, including details of the animal parts used, and their preparation and administration.

Bats host the highest number of zoonotic viruses per species, including: coronaviruses (e.g., MERS and SARS), lyssaviruses (e.g., rabies), filoviruses (e.g., Marburg viruses and potentially Ebola viruses), and henipaviruses (e.g. Nipah and Hendra viruses) [18]. Bat-associated zoonoses are of public health concern but the zoonotic origins and modes of transmission of many such diseases remain obscure [29-31]. For example, African fruit bats have been implicated as putative reservoirs of filoviruses responsible for viral hemorrhagic fever outbreaks [32-34], but documenting how spillover transmission occurs has proven challenging $[42,43]$. Much of the attention surrounding human-bat interactions has focused on more visible forms of contact (e.g., hunting, butchering, and consumption) [37-43]. In addition to being hunted for food, bats are used in zootherapies globally, including the use of small "house" bats, bat fat, and bat 
teeth for medicinal and cultural purposes in Nepal, Pakistan, and Malaysia, respectively [44-46]. Bats are also used to cure asthma, arthritis, and fever in Bangladesh [40], to enhance female fertility in Nigeria [47, 48], and are sold widely in traditional medicine markets in Benin [27]. The widespread use of bats as zootherapy in areas where they are hunted and traded for bushmeat warrants deeper investigation into the potential role of zootherapy as a zoonotic risk factor [22].

Genetic similarity between humans and non-human primates may facilitate the transmission of a disproportionate number of zoonoses [49]. Primates are reservoirs of simian retroviruses that appear to regularly spillover into humans $[50,51]$, and in some cases evolved into epidemic or pandemic AIDS viruses [52]. Research and narrative surrounding the origins of AIDS is largely responsible for the current emphasis on bushmeat hunting as a major mode of zoonotic exposure [53-56]. Primates have also played roles in the transmission of Ebola virus $[57,58]$ and anthrax [59] to humans. In addition to being hunted for their meat, primates are widely used in zootherapies, with one literature review indicating that 101 species of primates are used in traditional folk practices and magic-religious rituals globally [21]. Contact with non-human primates via zootherapy may therefore be an unappreciated risk factor for exposure to primate pathogens globally.

Although rodents, bats, and primates occupy most of the thinking surrounding spillover transmission, there is a need to examine human contact with other taxa that serve as reservoirs or facilitate transmission to humans $[16,60,64]$. For example, wild ungulates have also been implicated in anthrax transmission [62] and possibly involved in the natural ecology of Ebola virus [57, 63]. Domestic animals can also play an important role in the transmission ecology of wildlife pathogens, acting as amplification hosts that facilitate transmission to humans (e.g., Nipah and Hendra [61]). Indeed, domestic animals (primarily ungulates and carnivores) share a large number of infectious disease with humans $[16,60]$ and feature as both ingredients in and recipients of zootherapies globally $[4,9]$.

Deciphering potential zoonotic risks associated with zootherapy requires understanding human-animal interactions beyond simple tallies of species encounters and the purpose of their use. For example, zoonotic risks associated with zootherapy will depend, in part, on the animal product used and how it is prepared and administered. Zootherapeutic practices may be particularly risky when they involve direct contact with animals and their by-products (especially blood, urine, and feces), do not include heat inactivation during preparation (e.g., boiling, singing, smoking, grilling), or employ subcutaneous (e.g., sharp injuries or splashes leading to exposure to broken skin or mucosa), topical (e.g., skin, eyes, ears, nose, vagina, rectum), inhalation, or oral routes of administration. Hunting and butchering of animals prior to preparation into zootherapeutic products poses additional points of contact that have been subject to extensive examination (e.g., $[11,12,72])$. However, current examinations of zootherapy are only minimally informative for understanding these practices. To our knowledge there has been no previous examination of zootherapy from a perspective that examines potential zoonotic risks, for instance, by including information on the part of the animal, and details on its preparation and administration that might affect exposure risks (see Additional File 1 for search strategy). Attention to broader social, cultural, 
and ecological contexts of animal use is additionally important for understanding the factors that influence potential public health risks and for designing effective and appropriate interventions [73-75].

Here, we characterize human-wildlife interactions shaped by zootherapy where hunting and zootherapy are core components of local cultures and livelihoods [11]. Our goal was to examine zootherapeutics across the diversity of animal taxa hunted, including details of the body parts used and how they were prepared and administered, to gain a comprehensive picture of the scope and scale of human-animal interactions via zootherapy and qualitatively assess exposure risks. We additionally examine the sociocultural factors that shape zootherapeutic use through mixed-methods analysis of the importance of different animals and body parts for zootherapies, and the sociodemographic and place-based factors that promote their use. Together, these data reveal potential risks associated with zootherapy and some of the sociocultural determinants of their use.

\section{Methods}

\section{Study site}

This study describes the cultural and medicinal uses of wildlife reported by communities within and near Cross River National Park in Southern Nigeria, where wild animals are both nutritionally and economically valuable [76], and are important components of traditional medicine and cultural practices [11, 77]. Cross River National Park is characteristic of lowland rainforest, forming a mosaic of disturbed and relatively undisturbed forest patches. Overall, our study included nine villages representing four ethnic groups (Ejagham [ $=3$ communities], Boki [ $=2]$, Ayo [ $=3]$, and Idoma [ $=1]$ ). Villages were categorized by their location relative to the national park (i.e., within the park, within park buffer zone, outside of the park).

Social organization across our study area is based on politically decentralized villages with several clans under the leadership of chiefs. People are traditionally polytheistic, with beliefs and folklore centered on Sky, Earth, and Water Gods and a forest environment filled with supernatural beings [24]. Human-animal relationships are featured in nearly every aspect of cultural history in the region; including, religious beliefs, folk-lore, art, secret societies, juju (i.e., charms and spells), gender identities, birth customs, initiations, and funerals [78]. Throughout the region, people engage in a mixed economy of hunting, gathering, and farming, subsisting off cultivated staple foods (e.g., cassava, yam, maize), as well as wild and cultivated fruits, vegetables, and animals. Study communities were accessible by vehicle, motorbike, boat, and/or by foot only, and had variable access to government healthcare facilities. Two of the villages were designated as "enclaves" within Cross River National Park and had no formal health care workers or active medical facilities during our study period. Villages in the support zone had more active health care centers with variable presence of healthcare workers and resources.

The study team has extensive research and lived experience within the region, which helped us to cultivate relationships of confidence within the communities. SF has worked within Cross River National 
Park communities for 15 years and WAA, AOA, NMI, and OMO are from southern Nigeria. All study team members that were engaged in data collection lived within each village for a minimum of one month during data collection, where we participated in community work events, hunting excursions, community meetings, and festivals. Together, these shared experiences helped to enhance our awareness of sensitivity of topics, further build confidence with respondents, and aided our analyses.

\section{Data collection and analysis}

We collected data over two periods (2012 and 2017) as part of two larger studies focused on humananimal interactions via hunting [11] and consumption [76, 79] of bushmeat. Here, we compiled data on zootherapeutic practices to investigate broader patterns and contexts of human-animal interactions in communities that hunt and consume wildlife. In 2012, we administered questionnaires orally to hunters who were purposively selected and then matched with randomly selected non-hunters in five communities ( $n=327$ males); however, because participants who did not identify as hunter continuously revealed engagement in hunting activities, the resulting sample had a disproportionate number of hunters $(n=188)$ compared to non-hunters [11]. During individual interviews, we used species lists and published drawings to elicit zootherapeutic uses of wildlife [80]. Following a series of multiple-pass questions, where we used drawings and local names of wild animals to elicit information on hunting and consumption practices, we asked people if any of the animals shown, or any other animal, was used for medicinal purposes. If a respondent answered "yes", we asked them to identify the species and body part, describe the methods of preparation and administration, and give the purpose of its use. We then asked participants if they had personally used any of the listed medicinal uses for themselves or their dependents. We then repeated the same process, asking participants to identify other uses of wild animals for cultural purposes, providing them with the examples of festival/ceremony, sacrifice, or charm. We collected additional sociodemographic information on age (years), household size (number), engagement in hunting or trapping animals in previous year $(y / n)$, education level (primary school) beyond primary school), wealth (0-16), and awareness of zoonoses $(y / n)$ (see [11] for additional details). We used logistic regression to examine the effect of age, household size, engagement in hunting, education, wealth, zoonotic disease awareness, and village location on individual use of animals for medicine. We used backward elimination of predictor variables, initially including all variables in the model, but retaining only significant variables $(a<0.05)$ and first order interactions among significant main effects in the final model. We performed analyses with $\mathrm{g} / \mathrm{m}$ function in RGui (4.0).

In 2017, we collected additional data on the cultural salience (i.e., importance/ cognitive accessibility) of different animals used for zootherapy. Specifically, we used free-listing and ranking exercises with key informants ( $n=50$ [average $=8$ per village], representing 34 men and 16 women), recruited to include people with specialist knowledge of wild animals (e.g., hunters and traders, restaurant owners, traditional healers). We asked participants to free-list and then rank representative images of animals ( $1=$ most important) across different domains, including medicinal and cultural practices. We asked other questions first, including the importance of animals for hunting, money, and taste preferences, which 
allowed participants to warm up into more sensitive questions about medicinal and cultural practices (published elsewhere [76, 79]). We then elicited further details on zootherapeutic uses via follow-up questions during free-listing exercises, including part of the body, purpose of its use, and details on preparation and administration. To determine the importance of different animals used for zootherapy, we constructed salience plots using salience index (Smith's S) combining the average rank assigned to each animal and the frequency it was mentioned as useful for medical uses or cultural purposes [81]. Freelists were analyzed in R statistical software using the AnthroTools package [82].

\section{$S=\sum \frac{\text { inverted item rank } / \text { \#items }}{\text { \# informants }}$}

We organized descriptions of medicinal and other cultural uses from 2012 and 2017 into tables indicating the animal used, the number of times the animal was mentioned, the body part used, the purpose of its use, and details of preparation and administration practices. Zootherapies were considered distinct if they involved different species, parts of the body, were used for different and unrelated purposes, or varied in their preparation (e.g., use of raw vs. cooked parts) or administration (e.g., applied orally vs. topically). Treatments involving different body parts, but applied together, were treated as a single zootherapy. Several taxa could not be reliably identified due to low taxonomic certainty by informants. These taxa were grouped in our analyses at the most specific taxonomic group possible: monkeys, bats, pottos, galagos, pangolins, and fish.

\section{Results}

\section{Zootherapies}

We recorded a total of 292 zootherapeutic uses, including 172 medicinal uses and 120 other cultural uses of animals (Additional File 2). Animals were used as traditional medicine for purposes including treatment for various injuries and ailments from burns to epilepsy, behavioral problems (e.g., nighttime incontinence), mental problems, and as cure for poisoning. Animal parts were also used as vessels for medicine (e.g., skulls and shells to make, hold, and deliver medicine) and as health promoters (e.g., bones to confer strength). Other cultural practices included the use of animals for: ceremonial consumption (e.g., for festivals or major life events), sacrifice, charms/juju (e.g., spells used in religious practice, for protection, or good fortune), display (e.g., decoration or prop), gifts, payment of fines, tools, and as a poison.

\section{Animal use}

Zootherapeutic practices involved a minimum of 44 different species, including wild and domestic animals (Fig. 1A; see Additional File 2 for taxonomic information). Animals known to be consumed locally, but that were not reported as useful for zootherapy included: golden cat (Caracal aurata), tree and 
rock hyraxes (Dendrohyrax dorsalis and Procavia capensis), giant otter shrew (Potamogale velox), otter (Aonyx capensis), mongooses (Bdeogale nigripes and Crossarchus obscurus), and unknown species of locally sourced and imported fish. Chameleons were the only animals used for medicine but not otherwise known to be consumed.

The most medicinally salient animals (Smith's $S \geq 0.05)$ included: python $(S=0.17)$, tortoise $(S=0.11)$, flying squirrel $(S=0.08)$, water chevrotain $(S=0.08)$, elephant $(S=0.06)$, and potto $(S=0.05)$ (Fig. $2 A$; see Additional File 2 for specific practices). Goat $(S=0.20)$, red duiker $(S=0.17)$, porcupine $(S=0.07)$, chicken $(S=0.07)$, blue duiker $(S=0.06)$, elephant $(S=0.06)$, and leopard $(S=0.05)$ were considered highly salient animals for non-medicinal cultural practices (Fig. 2B; see Additional File 2 for specific practices).

\section{Animal parts, preparation, and administration}

Zootherapeutic practices involved the use of meat, hard parts (e.g., bone, skull, shell, beak, horn, scales, spines, teeth and tusks), skin, whole animals and whole animal parts (e.g., limbs or head, including skin, bone, and organs), internal organs (e.g., brain, gall bladder, intestine, kidney, pancreas, heart, scent gland, stomach, and gizzard), "other parts" (e.g. bone marrow, ears, eyes, tail, feather, whiskers, egg, and anus), feces, other bodily fluids (e.g., bile, stomach fluid, synovial fluid, and snake venom), fat, fur, blood, and unknown parts (Figs. 1B and 3; Table 1).

Zootherapies were prepared using live animals, raw animal parts and by-products, or by applying direct heat (e.g., cooked, boiled, dried, or melted using fire), passive heat (e.g., air or sundried), or liquor (e.g., distilled palm wine) to animal parts and by-products (Table 1). 
Table 1

Body parts used for zootherapy, their preparation, administration, and taxonomic classification of animals used

\begin{tabular}{|c|c|c|c|c|}
\hline Body part & $\#^{1}$ & preparation & route & taxonomic groups used \\
\hline \multirow[t]{7}{*}{ meat } & 68 & direct heat & oral & $\begin{array}{l}\text { any animal, ungulate, domestic chicken, } \\
\text { primate, reptile, domestic dog, carnivore, } \\
\text { rodent, crab, domestic ungulate }\end{array}$ \\
\hline & & & oral (extract) & reptile, primate, ungulate \\
\hline & & & subcutaneous & primate, ungulate \\
\hline & & & topical (skin) & ungulate \\
\hline & & raw & topical (eye) & snail \\
\hline & & $\begin{array}{l}\text { raw or direct } \\
\text { heat }\end{array}$ & $\begin{array}{l}\text { non-specific } \\
\text { contact }\end{array}$ & $\begin{array}{l}\text { any animal, ungulate, carnivore, domestic } \\
\text { ungulate, rodent, reptile, elephant, bird }\end{array}$ \\
\hline & & unknown & unknown & ungulate \\
\hline \multirow[t]{8}{*}{ skin } & 48 & passive heat & topical (skin) & $\begin{array}{l}\text { carnivore, ungulate, domestic cat, reptile, } \\
\text { primate, pangolin, elephant }\end{array}$ \\
\hline & & & unknown & ungulate, rodent, carnivore, pangolin \\
\hline & & & $\begin{array}{l}\text { non-specific } \\
\text { contact }\end{array}$ & $\begin{array}{l}\text { reptile, domestic cat, carnivore, domestic } \\
\text { ungulate }\end{array}$ \\
\hline & & & oral (extract) & reptile \\
\hline & & direct heat & oral & ungulate, carnivore, reptile \\
\hline & & & topical (skin) & reptile \\
\hline & & & oral (extract) & ungulate \\
\hline & & & $\begin{array}{l}\text { topical } \\
\text { (inhaled) }\end{array}$ & ungulate \\
\hline \multirow[t]{5}{*}{ hard parts } & 42 & $\begin{array}{l}\text { dried (various } \\
\text { mechanisms) }\end{array}$ & topical (skin) & $\begin{array}{l}\text { ungulate, primate, reptile, elephant, crab, } \\
\text { rodent }\end{array}$ \\
\hline & & & unknown & bird, reptile, elephant, primate, ungulate \\
\hline & & & enema & primate, ungulate, reptile \\
\hline & & & subcutaneous & primate, ungulate, rodent, reptile \\
\hline & & & $\begin{array}{l}\text { non-specific } \\
\text { contact }\end{array}$ & ungulate, primate, snail, elephant \\
\hline
\end{tabular}

${ }^{1}$ Indicates the number of zootherapies a body part was used in. 


\begin{tabular}{|c|c|c|c|c|}
\hline \multirow[t]{7}{*}{ Body part } & $\#^{1}$ & preparation & route & taxonomic groups used \\
\hline & & & $\begin{array}{l}\text { no direct } \\
\text { contact }\end{array}$ & domestic chicken, reptile, elephant \\
\hline & & & oral & primate, reptile \\
\hline & & & topical (eye) & snail \\
\hline & & direct heat & oral & ungulate, pangolin, reptile \\
\hline & & & enema & reptile \\
\hline & & & $\begin{array}{l}\text { topical } \\
\text { (inhaled) }\end{array}$ & rodent \\
\hline \multirow{6}{*}{$\begin{array}{l}\text { whole } \\
\text { animal/parts }\end{array}$} & 41 & unknown & unknown & reptile, bird, primate, carnivore \\
\hline & & $\begin{array}{l}\text { raw or direct } \\
\text { heat }\end{array}$ & $\begin{array}{l}\text { non-specific } \\
\text { contact }\end{array}$ & $\begin{array}{l}\text { domestic ungulate, elephant, primate, } \\
\text { rodent, ungulate, domestic chicken, reptile }\end{array}$ \\
\hline & & live & $\begin{array}{l}\text { non-specific } \\
\text { contact }\end{array}$ & domestic dog, domestic chicken \\
\hline & & direct heat & oral & ungulate, domestic chicken \\
\hline & & unknown & topical (skin) & reptile, pangolin \\
\hline & & rinsed & $\begin{array}{l}\text { enema } \\
\text { (extract) }\end{array}$ & elephant, domestic dog \\
\hline \multirow[t]{7}{*}{$\begin{array}{l}\text { internal } \\
\text { organs }\end{array}$} & 20 & direct heat & oral & $\begin{array}{l}\text { bat, reptile, rodent, ungulate, domestic } \\
\text { chicken }\end{array}$ \\
\hline & & & oral (extract) & reptile, primate, rodent \\
\hline & & & topical (skin) & reptile \\
\hline & & raw & topical (skin) & carnivore, reptile \\
\hline & & & $\begin{array}{l}\text { non-specific } \\
\text { contact }\end{array}$ & domestic cow \\
\hline & & liquor & oral (extract) & rodent, reptile \\
\hline & & unknown & unknown & bird, ungulate, carnivore \\
\hline \multirow[t]{4}{*}{ other parts } & 20 & direct heat & oral & bird bone marrow, ungulate ear \\
\hline & & unknown & unknown & bird eye \\
\hline & & raw & topical (skin) & bird feathers \\
\hline & & raw & unknown & bird feathers \\
\hline
\end{tabular}




\begin{tabular}{|c|c|c|c|c|}
\hline Body part & $\#^{1}$ & preparation & route & taxonomic groups used \\
\hline & & raw & oral & carnivore whiskers \\
\hline & & raw & $\begin{array}{l}\text { non-specific } \\
\text { contact }\end{array}$ & domestic chicken egg \\
\hline \multirow[t]{4}{*}{ feces } & 13 & dried or fresh & topical (skin) & ungulate, reptile, elephant, carnivore \\
\hline & & & subcutaneous & elephant, reptile \\
\hline & & & enema & carnivore \\
\hline & & liquor & oral (extract) & elephant, primate \\
\hline \multirow[t]{4}{*}{ fat } & 11 & raw & topical (skin) & reptile \\
\hline & & direct heat & subcutaneous & domestic dog \\
\hline & & direct heat & oral & reptile, elephant \\
\hline & & unknown & unknown & reptile \\
\hline \multirow{3}{*}{$\begin{array}{l}\text { other bodily } \\
\text { fluids }\end{array}$} & 10 & liquor & oral & reptile, elephant \\
\hline & & raw & oral & elephant \\
\hline & & antivenom & intravenous & reptile \\
\hline \multirow[t]{3}{*}{ fur } & 8 & raw & topical (skin) & bat, carnivore, primate, rodent \\
\hline & & & oral & rodent, primate \\
\hline & & & subcutaneous & domestic dog \\
\hline \multirow[t]{2}{*}{ blood } & 4 & raw & $\begin{array}{l}\text { non-specific } \\
\text { contact }\end{array}$ & $\begin{array}{l}\text { domestic dog, domestic chicken, domestic } \\
\text { ungulate }\end{array}$ \\
\hline & & raw & topical (skin) & primate \\
\hline unknown & 4 & & & \\
\hline
\end{tabular}

Consumption of cooked or dried meat from domestic and wild animals was commonly described for medicinal and cultural practices, with specific species being important under different circumstances (e.g., porcupine to welcome guests and potto to give strength to an unborn child [Additional File 2]). We found no examples of the use of raw meat for traditional medicine, except for the use of raw snail meat as an eye rub. Dried meat and organs were used to prepare powders, and raw internal organs were mixed with liquor to produce medicinal extracts. Some participants reported that water could be used when liquor was not available. 
The condition of meat, or whole animal/ whole animal parts, that were shared within the community for ceremonial purposes or good fortune was non-specific, as they could be offered as raw/dressed meat, smoked/dried meat, or as a whole animal (dead or alive). Zootherapies involving live animals were only described for domestic species, presumably due to the difficulty of procuring live animals from the forest. During live sacrifices, the person performing the sacrifice would slaughter the animal, occasionally making use of the raw blood. In contrast, when wild animals were sacrificed, they were conventionally hunted and butchered, and the sacrifice involved sharing pieces of dry meat with gods or ancestors by sprinkling them on the ground. Participants also described using water after "washing" a live animal or whole animal parts to produce enemas for children.

Hard parts and skins were dried, either actively or passively, prior to their use in zootherapies. These parts were described as dried, but the same mechanism of drying was not consistently applied for a given use. For example, bones could be used after boiling (direct heat) or sun drying (passive heat). Similarly, skins were prepared by either passively drying them in the sun (e.g., for use as cultural displays), or directly heating them via roasting over a smoking fire. Feces were used either fresh or dried, with dried feces being mixed with water prior to use to prepare a rub, syrup, or enema. Animal fat was dried to prepare lozenges, or molten to prepare rubs or syrups. Blood and other bodily fluids were used raw to prepare rubs and tonics or mixed with liquor prior to consuming.

Animal parts were administered orally (direct or as an extract), topically (on skin, in eye, or inhaled), subcutaneously (in open cut or wound), as an enema, or were non-specific (Table 1). Orally administered zootherapies involved ingestion of food, broth, or drink made from animal parts, sucking on parts as a lozenge, or ingesting extract or mixture after an animal part had been mixed with liquor, water, or palm oil. Extracts or mixtures made from animal parts and by-products were also used as enemas for children. Topical applications included, wearing hard parts and skins, or using powders, molten fat, or feces as a body rub. Some treatments involved applying animal parts subcutaneously, by making incisions to an area before application or applying animal parts or by-products directly to an open wound. Contact with animal parts that were gifted, used as a vessel or instrument, or displayed in the house, were categorized as "non-specific contact", as the ways in which people handled these items were not specified or consistent. For example, a person gifting meat as part of a cultural practice could be involved in hunting, butchering, and smoking meat prior to gifting, or could have meat sent to someone else by the hunter without any direct contact.

Few zootherapies adhered to a common prescription. For example, we found numerous examples illustrating that for a single zootherapy, there may be variations that substitute different species (e.g., bat and galago fur instead of flying squirrel to treat burns and African civet, palm civet, and domestic cat skin instead of leopard skin), body parts (e.g., either blue duiker meat or organs used to cure stomachache), or preparation methods (e.g., elephant feces mixed with snuff, liquor, herbs, or used raw prior to application). Administration practices were also highly variable, for example, four different administration routes for gorilla bone were described by four different respondents who described their use for giving strength to a child, including: tying a bone to a child's neck, grinding the bone for consumption, mixing ground bone 
with herbs to perform a ritual, or using ground bone in an enema. Other variations were also cited that involved the use of other primate species and parts to confer strength (e.g., drill monkey, chimpanzee, and potto). Details can be found in Additional File 2.

Animals and animal by-products used for zootherapy were procured by anyone in the community with the skills and tools to acquire them. Medicinal treatments were then prepared by anyone with the knowledge of how to prepare and administer them. In contrast, many cultural practices, such as charms, were prepared only by juju doctors with specialized knowledge and power. Still, juju doctors often requested that customers bring the necessary animal parts to create charms, requiring users to procure the animal directly or sponsor a hunter to kill the animal on their behalf.

\section{Limits to participant knowledge}

Forty zootherapies included incomplete information regarding the parts used or how they were prepared or administered (Additional File 2). For example, participants reported using animals to provide protection against machetes and bullets, as aircraft charms that allow a person to be transported from one area to another, and for transformation into an animal, but they were either unable or unwilling to provide details on how the animals were used as these were held as trade secrets by juju doctors. Similarly, the details of animals used by secret societies, including sacrificial practices, were also kept secret by initiates. Trading in wild animal parts was another reason for incomplete knowledge, because "strangers" from other parts of Nigeria came to buy animal parts for medicine, but respondents themselves did not know the details of their use.

\section{Quantitative and qualitative differences in zootherapy users}

Forty-five percent $(n=147)$ of 327 participants reported knowledge of use of wild animals for medicine, and $75 \%(n=245)$ reported other cultural uses of wildlife. Nineteen percent $(n=62)$ reported using wild animals as medicine for themselves or their households. Use of wildlife for traditional medicine was positively associated with hunting for a livelihood ( $\mathrm{OR}=2.47$ [95\% Cl: 1.35-4.7]; $p<0.01)$. Age, family size, wealth, awareness of zoonotic disease, or village location in relation to the national park were not significantly associated with use of wildlife for medicine (see Additional File 3 for quantitative data). Qualitative analyses of zootherapies revealed seasonal as well as gender and age specific uses. For example, animals were used for medicine to treat women's breast problems, for maternal and antenatal care, to treat children's cough, heat stroke, weakness, and to promote children's intelligence. Animals were also used during cultural practices of male-only secret societies (e.g., practices of the leopard society), and for celebration of seasonal festivals (e.g., New Yam Festival) and treatment of seasonal ailments (e.g., catarrh or malaria). In at least one village, the celebration of the yam harvest involved ordering all men in the village to enter the forest and hunt in preparation for the festivities, regardless of whether they were "hunters". 


\section{Discussion}

Our study of hunting communities in Nigeria investigates zootherapy from a zoonotic risk perspective, examining not only which animals people use for zootherapy, but how they use them (i.e., body parts used and preparation and administration practices). In addition, we analyze the sociocultural contexts of these interactions to achiever a deeper understanding of the role of zootherapy in a society which it is practiced. Our findings reveal potential zoonotic risks, generate hypotheses for epidemiological investigations of zoonotic origins, and identify possible entry points for effective reduction of human exposures to zoonoses through zootherapeutic practices.

\section{Species encounters via zootherapy}

Zootherapies included use of both wild and domestic animals, including birds, rodents, primates, bats, ungulates, carnivores, reptiles, invertebrates, elephants, and pangolins. Animal groups and species varied in their importance in zootherapies, with wild animals most important for use in traditional medicine and domestic animals among the most important species used for other cultural purposes (Smiths $S \geq 0.05$; Figs. $1 \mathrm{a}$ and $2 \mathrm{~b}$ ). These data show that practices related to zootherapy promote human contact with high consequence groups (rodents, bats, and primates), and that within these groups nocturnal primates (potto/angwantibo) and porcupine are among the most culturally salient species used for medicine and other cultural practices, respectively.

Rodents were frequently reported as useful for zootherapy, offering potential routes for human exposures to rodent-borne zoonoses. Zootherapies included porcupine (family Hystricidae), giant pouched rats (genus Cricetomys), and flying squirrels (family Anomalure). Indeed, porcupines make up the majority of available mammal species sold as traditional medicine in markets across Africa [83] and are the preferred and most frequently hunted animals in our study region $[11,79]$. Zootherapies included use of extract from raw porcupine heart soaked in liquor, consumption of porcupine intestine (which is not otherwise widely consumed due to its bitter taste [76]), and use of quills as a laceration tool (Additional File 2). Such uses of porcupine illustrate how animal parts that are raw or might otherwise be discarded, and administration practices that permeate skin barriers, could lead to transmission of zoonotic agents. The existence of similar practices in other regions of Africa suggests any associated risks may be widespread; for example, porcupine intestine is also considered medicinal in Sierra Leone, when cooked in pepper soup (per obs., J. Bonwitt), and porcupine quills are used as a tool to puncture abscess and boils in Tanzania [84]. Similarly, the zootherapeutic use of giant pouched rats (meat, intestine, and gall bladder) was reported in our study and others across Nigeria, suggesting widespread potential for exposure to zoonoses hosted by Cricetomys spp. [47, 85-88].

Porcupine and giant pouched rats are both possible reservoirs for monkeypox virus, which is currently reemerging in Nigeria with poorly understood zoonotic origins [89-92]. However, we are unaware of the occurrence of monkeypox or other zoonoses hosted by porcupines or giant pouched rats and within our study villages. Cricetomys species and Old World porcupines have also been found to be infected with 
nairoviruses, the genus of bunyaviruses that includes Crimean Congo Hemorrhagic Fever [18, 93], and porcupines have been associated with anthrax outbreaks in other parts of West Africa [94]. Flying squirrels (family Anomalure) were among the most important species used for medicine. Flying squirrel fur was especially useful for treating burns (Additional File 2), again, paralleling zootherapies described in Sierra Leone [12] and suggesting extensive use of this zootherapy across West Africa. While other small rodents (e.g. mice and rats) are important household and agricultural pests throughout West Africa, they were not frequently consumed within our study communities [79], nor were they listed as useful for medicine or other cultural purposes. However, practices that might present a risk of zoonotic exposures to small rodents elsewhere include consumption of the intestine of the brush-tailed rat to ease stomach pain [12] and chewing a concoction of rodent feces wrapped in special leaves or eating of food leftover by rats to ease childbirth $[95,96]$. Epidemiological investigations of rodent-borne zoonoses should therefore explicitly consider zootherapy among possible routes of zoonotic exposures.

Primates were the second most cited group for medicinal uses, and third most common for zootherapies generally (Fig. 1A). Zootherapies involving non-human primates offered points of contact with body parts that were not typically consumed, including bones, feces, hands, skin, blood, and fur. For example, the use of chimpanzee blood, bone, and meat were reported to confer strength by participants of this study (Additional File 2) and in Sierra Leone (per. obs., J. Bonwitt). Several studies have identified multiple simian retroviruses that are transmissible to humans in West and Central Africa from blood exposure [50, $97,98]$. However, examination of risk factors for primate exposure and retroviral transmission have focused on hunting, butchering, and consumption of primates $[72,99,100]$. Our data demonstrate plausible routes for exposure to simian viruses, including blood, that extend beyond the hunting and consumption of bushmeat.

Bats were used as traditional medicine in our study population, including topical application of fur to treat burns and consumption of cooked brain to enhance children's intelligence (Additional File 2). Although bats were generally ranked as low importance for their zootherapeutic value in our study, the use of the heads of bats for zootherapy may introduce novel risks, as a diversity of lyssaviruses, rabieslike viruses with neurological tissue tropism, have been identified in bats of sub-Saharan Africa [101]. Similar reports from traditional healers in Senegal revealed frequent use of both heads and whole bodies of the Rüppel's Horseshoe bat in potions brewed for the treatment of mental illness [102]. Other zootherapeutic uses of bats described elsewhere include the inhalation of smoke from burning bats to treat pneumonia in Tanzania [84] and consumption of bat meat to improve female fertility and celebrate religious festivals in other regions of Nigeria $[47,48]$. Bats are also sold in traditional medicine markets by $49 \%$ of traders in Benin [27] and $21 \%$ of traders in South Africa for "unknown reasons" [83].

Contacts with domestic animals via zootherapy were qualitatively different from contacts with wild animals in that domestic animals were more likely to be used in cultural (vs. medicinal) practices, involved contact with live animals, such as live sacrifices, and were more likely to make use of animal blood. Although zoonoses from domestic animals are less likely to emerge than zoonoses from wildlife [103], domestic species host many zoonotic pathogens and can play important roles as intermediate 
hosts of wildlife-origin pathogens $[19,104]$ to which humans may be exposed. Future studies should also explore the use of zootherapy to cure animal diseases, given that traditional healers are also important parts of veterinary health care systems across developing countries [105], and domesticated animals can act as bridge or amplifier hosts to facilitate transmission of wildlife-origin pathogens to humans.

Other taxonomic groups used for zootherapy included pangolins, elephants, and reptiles, as well as domestic and wild birds, carnivores, and ungulates. Pangolins were used locally and were traded for unknown zootherapeutic purposes. Pangolins are also used widely for zootherapy in other regions of Nigeria [106, 107], other African countries [108, 109], and globally [110]. Recent characterization of coronaviruses similar to SARS-CoV-2 in pangolins in Asia suggests potential emerging infectious disease risks associated with pangolin trade [111]. Indeed, trade in pangolins for their medicinal properties has contributed to the near extinction of Asian pangolins, and redirected attention to African pangolins to meet demand [112], highlighting the potential zoonotic significance of human-pangolin interactions through zootherapy at multiple geographic scales.

In Nigeria, zootherapy often extends to animals not typically used for human consumption, including amphibians, skinks, shrews, small birds and rodents, and some insects [7]. However, we only identified one animal, the chameleon, used for medicine, but not otherwise consumed. While no species was considered universally taboo in our study communities, some family rules forbid consumption of certain species due to family mythologies [11]. Nevertheless, studies have shown that people will often kill, sell and/or use medicinal concoctions of animals that are undesirable or taboo to eat $[7,12,22]$. In such cases, taboos do not necessarily preclude their use among the wider community, and interactions with such species through zootherapy can remain a source of zoonotic infection. Focusing on hunting for consumption alone can therefore blind researchers to human-animal interactions and potential zoonotic exposures through zootherapy.

Our results show that human-animal interactions with species via zootherapy are not static in space and time, as use of certain animals is subject to availability of ingredients within ecological and cultural settings, and in relation to broader trade networks, and socioeconomic constraints [113]. For example, early ethnographic accounts from our study region describe uses of animals such as leopards and manatees in zootherapy in this region of Nigeria [78], however; species declines prohibit their availability for such uses in modern contexts. Indeed, we identified high plasticity in zootherapeutic practices, including several examples of zootherapies involving the replacement of rare animals with more common or domestic species (e.g., replacement of leopard parts with those from other wild and domestic cats). The use of bat fur to cure burns also appeared to be an adaptation of the more common practice of using flying squirrel fur. Species that do not have specific zootherapeutic uses at a certain place and time may have been used in the past or may act as a substitute for similar animals in the future.

\section{Zootherapeutic practices that can modify exposure risks}


Our data provide insight into zootherapeutic prescriptions, including preparation and administration practices, that may increase or decrease risk of potential exposure to zoonotic pathogens. Use of animal parts and by-products within zootherapies that would otherwise be discarded creates unique forms of interspecies interactions that may generate zoonotic exposures. For example, the use of feces, especially from primates, in many medicinal concoctions could facilitate the spread of enteric pathogens with infective stages that are shed in feces [114, 115], whereas the use of chimpanzee blood could facilitate transmission of blood-borne pathogens, such as simian retroviruses. The practice of using animal brains and skulls may generate exposure to lyssaviruses, rabies-like viruses with neurological tissue tropism [93]. In addition, therapies that make use of dried animal parts (e.g., powders or animal skins) may pose a unique risk for zoonotic pathogen exposures. Animal skins have been implicated as a source of anthrax spores in endemic countries and through trade in animal parts [116], and other pathogens such as orthopoxviruses, including monkeypox, can have substantial lengthy environmental survival in tissue [117]. Our data highlight that low-utility animal parts that do not feature prominently in diets are still handled within communities via zootherapeutic practices, creating novel exposure risks.

Exposure risks may be mitigated or exacerbated by preparation and administration practices, which are not widely reported in zootherapy research. For example, practices that heat inactivate or soak animal parts and by-products in alcohol prior to their administration may reduce exposure risks. Time and temperature needed for pathogen inactivation is significantly affected that the type of microorganism and where it is located (e.g., tissue vs. feces) [118]. Given the variation in heating techniques (e.g., boiling, smoking, sun-drying) applied to a wide diversity of animals and animal parts, we expect higher variability in exposure risks associated with handling animals for zootherapy compared to hunting and consumption. Similarly, the use of local alcohol (traditionally, distilled palm wine) to prepare zootherapies could help to inactive some pathogens. However, disinfecting properties of locally produced alcohol are unknown. A $60 \%-70 \%$ alcohol solution is recommended for sterilizing contaminated objects in healthcare settings [119]. Studies from Nigeria show that locally distilled palm wine ranges from $41-78 \%$ alcohol [120], though the range is likely larger due to variation in distillation methods as well as the common practice of diluting local liquor with water. Even at high alcohol levels, liquor may be ineffective in deeper tissues, and reports of substituting liquor with water would negate any possible risk reduction associated with this practice. Importantly, preparation norms that may reduce risks to end-users' would not decrease exposure risks in individuals procuring and preparing animal products.

Zootherapy administration practices included subcutaneous, topical, inhalation, oral, and anal exposure routes that alter the way that animal products and potentially infectious pathogens can enter the body. Parenteral (non-oral) routes of administration that by-pass the skin and mucous membranes may increase infection risks beyond what which would be expected from hunting and consumption of animal products. For example, the common practice of making incisions is likely to enhance infection risks from zoonotic pathogens as well as general infection from use of non-sterile products. Inhalation routes were described for zootherapies involving ungulates and rodents, which are known to transmit anthrax and hanta- and arena viruses, respectively. Rodent-borne hantaviruses and arenaviruses can be transmitted when virus particles are aerosolized on dust particles, such that people are advised to avoid raising dust 
to reduce chances of breathing it in $[122,123]$. Variation in administration practices could in turn affect the type and severity of disease; for example, the illness associated with anthrax varies depending on how it enters the body, with inhalation anthrax considered to be the deadliest form [121].

In our study, relatively few zootherapies included administration of live animals, fresh parts, raw meat, or blood, suggesting that risks to end-users are low relative to those who procure and prepare zootherapies. For example, the use of animal blood was reported in only a few descriptions of zootherapies (domestic animals and primates). Still, the hunting and butchering of animals during or prior to their preparation for zootherapy involves extensive contact and environmental contamination with animal blood. It was difficult to pinpoint where blood exposures related to zootherapy might occur, because animals could be obtained by either hunters, healers, or end-users, and prepared by friends, family members, designated healers, or users. Future studies examining zootherapy value chains would be better suited to determine product preparation to further assess the risk of zoonotic exposures across these groups.

\section{Sociocultural contexts of zootherapeutic practice}

Nineteen percent of participants reported using zootherapy for themselves and their family, which is similar to other regions within Sub Saharan Africa (23\% in Uganda [124]). Use of zootherapies was patterned by livelihoods, with male hunters significantly more likely than male non-hunters to use animals for medicine for themselves and their family, perhaps due to ease of access to animals and enhanced knowledge of animals. Village proximity to the forest was not associated with the likelihood that individuals used zootherapies, despite observed differences in wildlife consumption between these areas [76]. Together, these data show that zootherapy is widespread in our study region, but that increased use of animal products by hunters and their families may further contribute to heightened zoonotic exposure risks associated with hunting as an occupation.

Several zootherapeutic uses of animals were specific to certain groups (i.e., men, women, and children) or seasons, which could further pattern exposure risks. For example, some administration practices (e.g., enemas) and contact with certain animals and body parts (e.g., primate feces and bat brain) were limited to zootherapies that treated children. Other animals, including non-human primates and red duiker, featured prominently in zootherapies for prenatal care. Seasonal patterns (e.g., use of animals to treat seasonal infections such as malaria, cold/catarrh, and heat stroke, or for celebration of annual festivals or holidays) may further heighten contact in certain times of the year. Such information could be used for deciphering the epidemiology of zoonotic diseases and/or targeting interventions, for example, to hunters or including messaging about zootherapies in maternal healthcare programs.

Salient practices were difficult to define within our study area due to high variability in parts used and their preparation and administration. Indeed, traditional medicinal practices can be highly variable when: people practice do-it-yourself home remedies, treatments have high failure rates, practitioners compete with one another using different curative techniques, or treatments are prescribed within transitioning healthcare systems [125]. For instance, the value of traditional remedies can lay in their strangeness, 
which can conceal any uncertainty and lack of knowledge and further engender secrecy. High failure rates characteristic of traditional medicine can thus paradoxically encourage, rather than prevent, proliferation and diversification of cure. Variability in zootherapeutic practices may also reflect transitioning health systems that borrow from both local and global knowledge, combining "traditional" and "conventional" practices to meet the needs of local health systems and wildlife trade networks. In all, these results contribute to a growing number of examples showing that the practice of zootherapy in Nigeria is highly variable and lacks formulated standards or universal protocols $[6,7,87,126]$.

Our focus on people who prescribe, prepare, administer, and use zootherapies within the communities that source these animals provided a level of detail that is not always achievable in other settings, for example, trade markets. Like wildlife hunting and consumption, explorations of zootherapeutic uses of wildlife have largely focused on market surveys [85, 87, 126-129], which provide tallies of the species that are used, but offer limited information on the nature of their use due to limits in knowledge to traders who act as middlemen between hunters and end-users. Additionally, market surveys can miss species that are used locally but not widely traded [130]. Still, we were unable to determine details of animal use in zootherapies when people did not know, did not care to know, or did not want to reveal details of their practices. People may also keep certain details secret when protected species are used, patients do not want to reveal stigmatizing conditions (whether medicinal or related to witchcraft) [131], or traders do not want to expose trade secrets $[83,132,133]$. Though we tried to circumvent some of these challenges by asking about community-wide uses of animals, rather than exposing individual behavior, it is important to recognize that secrecy is embedded within traditional medicine, and there are inherent limits to the knowledge that we were able to obtain. This presents a challenge to identifying salient forms of zoonotic risks and developing interventions that target these practices.

Our data revealed some principles that may guide prescriptions of zootherapies in our study region and pattern an otherwise seemingly diverse set of practices. For example, some uses were based on bioactive components of animals (e.g., bile) or physical attributes of body parts (e.g., use of bones to give strength). Evidence from other studies shows that the condition of an animal (e.g. alive or dead) is sometimes determined by the raw materials to be extracted and the type of illness that is being treated [134]. Our results show common practices associated with different animal parts; for example, wearing or preparing powders from hard parts, using fat and feces to prepare body rubs, and ceremonial consumption of cooked meat. Public health messaging targeting administration practices for different animal parts may therefore be more effective than those that focus on specific zootherapies.

We found evidence that zootherapies were informed, in part, by sympathetic healing. For example, zootherapies included the use of skin and bones from "strong" animals for giving strength and making bullet proof charms or use of birds in making aircraft charms (Additional File 2). Pottos were used to promote strength of an unborn child when used by the pregnant mother [130]. These animals are known for their toughness and strength, with hunters reporting having to pry the animals off of tree branches after killing them [135]. The use of primate feces to cure cough was justified through observations of seeing monkeys cough in the forest; in this region where primates can serve as hosts for a zoonotic lung 
fluke that presents clinically with a cough [136]. Sympathetic healing also shapes contact with high risk taxa in other areas; for example, the consumption of remnants of food leftover by a rat by pregnant women to ease labor [95]. Similarly, heads and whole bodies of Rüppel's Horseshoe bat (Rhinolophus fumigatus) were used in traditional medicines for the treatment of mental illness because bats exist as a symbol of orientation, and therefore could aid patients who by the healer's judgment lacked mental orientation [102].

Our data also provide evidence of "like cures like" theory of healing, in which a substance capable of causing an illness or injury is also capable of curing it (e.g., the use of dog saliva to cure dog bites and snake teeth to cure snake bites). Similarly, python put into local liquor was used to prevent people from turning into a python and the bile of the python could be used to create and cure poison, depending on its preparation. Thus, while individual uses of animals were highly variable, there were patterns governing the underlying logic of their use. Indeed, the diverse use of zootherapies presents a major challenge to generalizable inclusion within public health messaging and interventions. Targeting the reasons for use of animals in medicinal and cultural practices, as opposed to specific zootherapies, may therefore be a more productive entry point for public health interventions.

\section{Study limitations}

Our study used a mixed-methods approach that focused primarily on community-wide practices to capture the breadth of zootherapies used within a single region and details of their preparation and administration. In doing so, we were unable determine the frequency by which certain products were used and how widespread their use was within and between populations. Future studies focusing on prevalence and frequency of use of different species, body parts, and preparation and administration practices across different subsets of society will be important for deciphering potential risks within these populations. Although zoonotic diseases such as monkeypox, Lassa fever, ebolavirus disease, and anthrax are known to either affect eastern Nigeria and other West African tropical rainforest communities, we do not have data on the presence of these zoonoses within our specific study communities, which have limited access to formal healthcare or diagnostic centers. Animal surveillance studies are needed to designate animals in these areas as reservoirs of zoonotic disease, and to provide direct evidence on the risks associated with different animal parts and practices. However, understanding the nature and contexts of human-animal interactions is important for assessing exposure risk. This paradigm has yielded a substantial body of research and knowledge surrounding hunting and consumption practices (e.g.,[11, 12, 72, 75, 137]), but insights into less visible forms of contact (i.e. zootherapy) have remained limited. Our mixed methods study provides a framework for examining practices in the context of zoonotic risks and generates hypotheses that will help guide surveillance for and epidemiological investigations of zoonotic pathogens.

\section{Conclusion}


Our study demonstrates the importance of understanding zootherapeutic practices as risk factors for zoonotic diseases. Our findings support previous calls to extend our understanding of the human-wildlife interface and zoonotic disease risk beyond bushmeat and bushmeat hunters $[3,138]$. Epidemiological investigations and research into animal-borne pathogens should broaden efforts to consider medicinal and cultural practices that involve human-animal contact. Furthermore, public health messaging about infection prevention and zoonotic transmission should be explicit in their inclusion of medicinal and other cultural uses of wildlife. Although responding to the economic and nutritional costs incurred from hunting bans is already challenging [139], the cultural uses of animals in traditional medicine and spiritual practices may be even more difficult. Interventions should therefore recognize cultural importance of zootherapies and focus on culturally acceptable risk mitigation, rather than curtailing or halting the practices themselves. Overall, the study of zootherapies, and design of public health interventions that incorporate the use of zootherapies to prevent zoonotic transmission will require mixed methods approaches and the efforts of social scientists alongside epidemiologists and health practitioners.

\section{Declarations}

\section{Ethics approval and consent to participate}

We obtained oral consent from all individual respondents included in the study. Oral consent was used due to low-literacy levels in our study population and because the consent document would have provided the only link between participants and their responses. Nigeria Health Research Ethics Committee (\#NHREC/01/01/2007-18/05/ 2017), and institutional review boards at the University of Wisconsin - Madison (\#SE-2011-0859), Hunter College of the City University of New York (\#2016-0352), and The Pennsylvania State University (\#00011190) approved all research activities included in this study. Community leaders approved the study and all study materials during sensitization meetings prior to any research activities.

\section{Consent for publication}

Not applicable

\section{Availability of data and materials}

All data generated or analyzed during this study are included in this published article [and its supplementary information files].

\section{Competing interests}

The authors declare that they have no competing interests. 


\section{Funding}

This study was funded by The National Science Foundation (SBE \#1604902; https://www.nsf.gov/; SF/JMR/JKJ/TLG), Primate Conservation Inc. (PCI\# 1381; SF/JMR), and City University of New York Research Foundation (PSC-CUNY; https://www.psc-cuny.org/; SF/JMR) Research Award Program. The funders had no role in study design, data collection and analysis, decision to publish, or preparation of the manuscript.

\section{Authors' contributions}

SF, JB, AJB, JKJ, JMR, and TLG led the conceptualization of the study and manuscript. SF, WAA, AOA, $\mathrm{NMI}, \mathrm{OMO}$, and CS collected and analyzed data. SF, JB, and AJB contributed to writing. All authors contributed to manuscript editing and read and approved the final manuscript.

\section{Acknowledgements}

The authors would like to thank Dr. David Ogar (University of Calabar, Nigeria), Dr. Clement Alawa (University of Abuja, Nigeria), and the Nigeria National Parks Service for their support in the field. We also thank our study communities for their kind hospitality and ongoing support. Specifically, we would like to thank Basil Ayu, Charles Ntui, Caring Ita, and John Mbui for their assistance as liaisons and translators within the communities. We also thank Paschal Oshen, Emelia Loomis, and Bill Rohde for their assistance with translations, logistics and training, and manuscript editing.

\section{References}

1. Wolfe ND, Daszak P, Kilpatrick AM, Burke DS. Bushmeat hunting, deforestation, and prediction of zoonotic disease. Emerg Infect Dis. 2005;11:1822-1827. http://wwwnc.cdc.gov/eid/article/11/12/04-0789.htm. Accessed 24 Jun 2014.

2. Tomley FM, Shirley MW. Livestock infectious diseases and zoonoses. Philos Trans R Soc Lond B Biol Sci. 2009;364:2637-42. doi:10.1098/rstb.2009.0133.

3. Paige SB, Frost SDW, Gibson MA, Jones JH, Shankar A, Switzer WM, et al. Beyond bushmeat: animal contact, injury, and zoonotic disease risk in Western Uganda. Ecohealth. 2014. doi:10.1007/s10393014-0942-y.

4. Souto WMS, Pinto LC, Mendonça LET, Mourão JS, Vieira WLS, Montenegro PFGP, et al. Medicinal Animals in Ethnoveterinary Practices: A World Overview. In: Alves RRN, Rosa IL, editors. Animals in Traditional Folk Medicine: Implications for Conservation. Berlin, Heidelberg: Springer Berlin Heidelberg; 2013. p. 43-66. doi:10.1007/978-3-642-29026-8_4.

5. Alves RRN, Rosa IL, Albuquerque UP, Cunningham AB. Medicine from the Wild: An Overview of the Use and Trade of Animal Products in Traditional Medicines. In: Alves RRN, Rosa IL, editors. Animals 
in Traditional Folk Medicine: Implications for Conservation. Berlin, Heidelberg: Springer Berlin Heidelberg; 2013. p. 25-42. doi:10.1007/978-3-642-29026-8_3.

6. Afolayan AJ, Yakubu MT. Erectile dysfunction management options in Nigeria. J Sex Med. 2009;6:1090-102. doi:10.1111/j.1743-6109.2008.01064.x.

7. Soewu DA. Zootherapy and Biodiversity Conservation in Nigeria. In: Alves RRN, Rosa IL, editors. Animals in Traditional Folk Medicine: Implications for Conservation. Berlin, Heidelberg: Springer Berlin Heidelberg; 2013. p. 347-65. doi:10.1007/978-3-642-29026-8_16.

8. Alves RRN, Alves HN. The faunal drugstore: animal-based remedies used in traditional medicines in Latin America. J Ethnobiol Ethnomed. 2011;7:9. doi:10.1186/1746-4269-7-9.

9. Alves RRN, Rosa IL. Why study the use of animal products in traditional medicines? J Ethnobiol Ethnomed. 2005;1:5. doi:10.1186/1746-4269-1-5.

10. Alves RRN, Rosa IML. Biodiversity, traditional medicine and public health: where do they meet? J Ethnobiol Ethnomed. 2007;3:14. doi:10.1186/1746-4269-3-14.

11. Friant S, Paige SB, Goldberg TL. Drivers of bushmeat hunting and perceptions of zoonoses in Nigerian hunting communities. PLoS Negl Trop Dis. 2015;9:e0003792. doi:10.1371/journal.pntd.0003792.

12. Bonwitt J, Kandeh M, Dawson M, Ansumana R, Sahr F, Kelly AH, et al. Participation of women and children in hunting activities in Sierra Leone and implications for control of zoonotic infections. PLoS Negl Trop Dis. 2017;11:e0005699. doi:10.1371/journal.pntd.0005699.

13. Bonwitt J, Sáez AM, Lamin J, Ansumana R, Dawson M, Buanie J, et al. At Home with Mastomys and Rattus: Human-Rodent Interactions and Potential for Primary Transmission of Lassa Virus in Domestic Spaces. Am J Trop Med Hyg. 2017;96:935-43. doi:10.4269/ajtmh.16-0675.

14. Van Vliet N, Moreno J, Gómez J, Zhou W, Fa JE, Golden C, et al. Bushmeat and human health: Assessing the evidence in tropical and sub-tropical forests. Ethnobiology and Conservation. 2017;6:1-45. http://ethnobioconservation.com/. Accessed 19 Jun 2018.

15. Langwick SA. The Political Promise of Traditional Medicine in Africa. Curr Anthropol. 2015;56:493514. doi:10.1086/682285.

16. Waldram JB. The Efficacy of Traditional Medicine: Current Theoretical and Methodological Issues. Med Anthropol Q.

17. Romero-Daza N. Traditional medicine in Africa. Ann Am Acad Pol Soc Sci. 2002;583:173-6. doi:10.1177/000271620258300111.

18. Zhang Q. Global situation and WHO strategy on traditional medicine. Traditional Medicine and Modern Medicine. 2018;01:11-3. doi:10.1142/s257590001820001x.

19. Zhang X. Traditional medicine and WHO. World Health. 1996. https://apps.who.int/iris/bitstream/handle/10665/330443/WH-1996-Mar-Apr-p4-5-eng.pdf.

20. van den Geest $S$. Is there a role for traditional medicine in basic health services in Africa? A plea for a community perspective. Trop Med Int Health. 1997;2:903-11. 
https://onlinelibrary.wiley.com/doi/abs/10.1046/j.1365-3156.1997.d01-410.x.

21. Gamaniel KS, Fakeye T, Sofowora A. Federal Republic of Nigeria. In: Bodeker G, Ong C-K, Grundy C, Burford G, Shein K, editors. WHO global atlas of traditional, complementary and alternative medicine. 2005. p. 27-32.

22. Han BA, Kramer AM, Drake JM. Global Patterns of Zoonotic Disease in Mammals. Trends Parasitol. 2016;32:565-77. doi:10.1016/j.pt.2016.04.007.

23. Johnson CK, Hitchens PL, Pandit PS, Rushmore J, Evans TS, Young CCW, et al. Global shifts in mammalian population trends reveal key predictors of virus spillover risk. Proc Biol Sci. 2020;287:20192736. doi:10.1098/rspb.2019.2736.

24. Olival KJ, Hosseini PR, Zambrana-Torrelio C, Ross N, Bogich TL, Daszak P. Host and viral traits predict zoonotic spillover from mammals. Nature. 2017;546:646-50. doi:10.1038/nature22975.

25. Luis AD, Hayman DTS, O'Shea TJ, Cryan PM, Gilbert AT, Pulliam JRC, et al. A comparison of bats and rodents as reservoirs of zoonotic viruses: are bats special? Proceedings of the Royal Society of London B: Biological Sciences. 2013;280:20122753. doi:10.1098/rspb.2012.2753.

26. Wolfe ND, Dunavan CP, Diamond J. Origins of major human infectious diseases. Nature. 2007;447:279-83. doi:10.1038/nature05775.

27. Cooper N, Griffin R, Franz M, Omotayo M, Nunn CL. Phylogenetic host specificity and understanding parasite sharing in primates. Ecol Lett. 12/2012;15:1370-7. doi:10.1111/j.1461-0248.2012.01858.x.

28. Alves RRN, Souto WMS, Barboza RRD. Primates in traditional folk medicine: a world overview. Mamm Rev. 2010;40:155-80. doi:10.1111/j.1365-2907.2010.00158.x.

29. Mildenstein T, Tanshi I, Racey PA. Exploitation of Bats for Bushmeat and Medicine. In: Bats in the Anthropocene: Conservation of Bats in a Changing World. Springer, Cham; 2016. p. 325-75. http://link.springer.com/chapter/10.1007/978-3-319-25220-9_12. Accessed 17 May 2018.

30. Han BA, Schmidt JP, Bowden SE, Drake JM. Rodent reservoirs of future zoonotic diseases. Proc Natl Acad Sci U S A. 2015;112:7039-44. doi:10.1073/pnas.1501598112.

31. Suwannarong K, Lantican C. Factors related to using rodents as traditional curing products. 2016. doi:10.14456/jhr.2016.20.

32. Solanki GS, Chutia P. Studies on ethnomedicinal aspects and zoo-therapy in tribal communities in Arunachal Pradesh, India. Journal of Ecology \& Environmental Science. 2009.

https://www.academia.edu/download/50223895/Studies_on_Ethno-

Medicinal_Aspects_and_Z20161109-6542-q9dhxk.pdf.

33. Edae M, Mohammed K. Indigenous zootherapeutic healing practices: among the Macca Oromo, Southwestern Ethiopia. Research \& Science Today. 2018. https://www.ceeol.com/search/articledetail?id=720368.

34. Djagoun CAMS, Akpona HA, Mensah GA, Nuttman C, Sinsin B. Wild Mammals Trade for Zootherapeutic and Mythic Purposes in Benin (West Africa): Capitalizing Species Involved, Provision Sources, and Implications for Conservation. In: Alves RRN, Rosa IL, editors. Animals in Traditional 
Folk Medicine: Implications for Conservation. Berlin, Heidelberg: Springer Berlin Heidelberg; 2013. p. 367-81. doi:10.1007/978-3-642-29026-8_17.

35. CDC. Diseases directly transmitted by rodents. 2018.

https://www.cdc.gov/rodents/diseases/direct.html. Accessed 26 May 2020.

36. Dobson AP. What Links Bats to Emerging Infectious Diseases? Science. 2005;310:628-9. doi:10.1126/science.1120872.

37. Smith I, Wang L-F. Bats and their virome: an important source of emerging viruses capable of infecting humans. Curr Opin Virol. 2013;3:84-91. doi:10.1016/j.coviro.2012.11.006.

38. Banerjee A, Doxey AC, Mossman K, Irving AT. Unraveling the Zoonotic Origin and Transmission of SARS-CoV-2. Trends Ecol Evol. 2020. doi:10.1016/j.tree.2020.12.002.

39. Swanepoel R, Smit SB, Rollin PE, Formenty P, Leman PA, Kemp A, et al. Studies of reservoir hosts for Marburg virus. Emerg Infect Dis. 2007;13:1847-51. doi:10.3201/eid1312.071115.

40. Ogawa H, Miyamoto H, Nakayama E, Yoshida R, Nakamura I, Sawa H, et al. Seroepidemiological Prevalence of Multiple Species of Filoviruses in Fruit Bats (Eidolon helvum) Migrating in Africa. $\mathrm{J}$ Infect Dis. 2015;212 Suppl 2:S101-8. doi:10.1093/infdis/jiv063.

41. Leroy EM, Kumulungui $B$, Pourrut $X$, Rouquet $P$, Hassanin $A$, Yaba $P$, et al. Fruit bats as reservoirs of Ebola virus. Nature. 2005;438:575-6. doi:10.1038/438575a.

42. Saéz AM, Weiss S, Nowak K, Lapeyre V, Zimmermann F, Düx A, et al. Investigating the zoonotic origin of the West African Ebola epidemic. EMBO Mol Med. 2015;7:17-23. doi:10.15252/emmm.201404792.

43. Leroy EM, Epelboin A, Mondonge V, Pourrut X, Gonzalez J-P, Muyembe-Tamfum J-J, et al. Human Ebola outbreak resulting from direct exposure to fruit bats in Luebo, Democratic Republic of Congo, 2007. Vector Borne Zoonotic Dis. 2009;9:723-8. doi:10.1089/vbz.2008.0167.

44. Kamins AO, Restif O, Ntiamoa-Baidu Y, Suu-Ire R, Hayman DTS, Cunningham AA, et al. Uncovering the fruit bat bushmeat commodity chain and the true extent of fruit bat hunting in Ghana, West Africa. Biol Conserv. 2011;144:3000-8. doi:10.1016/j.biocon.2011.09.003.

45. Kamins AO, Rowcliffe JM, Ntiamoa-Baidu Y, Cunningham AA, Wood JLN, Restif O. Characteristics and risk perceptions of Ghanaians potentially exposed to bat-borne zoonoses through bushmeat. Ecohealth. 2014;:1-17. doi:10.1007/s10393-014-0977-0.

46. Harrison ME, Cheyne SM, Darma F, Ribowo DA, Limin SH, Struebig MJ. Hunting of flying foxes and perception of disease risk in Indonesian Borneo. Biol Conserv. 2011;144:2441-9. doi:10.1016/j.biocon.2011.06.021.

47. Nahar N, Asaduzzaman M, Mandal UK, Rimi NA, Gurley ES, Rahman M, et al. Hunting Bats for Human Consumption in Bangladesh. Ecohealth. 2020;17:139-51. doi:10.1007/s10393-020-01468-x.

48. Euren J, Bangura J, Gbakima A, Sinah M, Yonda S, Lange CE, et al. Human Interactions with Bat Populations in Bombali, Sierra Leone. Ecohealth. 2020;17:292-301. doi:10.1007/s10393-020-01502y. 
49. Anti P, Owusu M, Agbenyega O, Annan A, Badu EK, Nkrumah EE, et al. Human-Bat Interactions in Rural West Africa. Emerg Infect Dis. 2015;21:1418-21. doi:10.3201/eid2108.142015.

50. Openshaw JJ, Hegde S, Sazzad HMS, Khan SU, Hossain MJ, Epstein JH, et al. Bat hunting and bathuman interactions in Bangladeshi villages: Implications for zoonotic disease transmission and bat conservation. Transbound Emerg Dis. 2017;64:1287-93. doi:10.1111/tbed.12505.

51. Tuladhar-Douglas W. The Use Of Bats As Medicine Among The Newars. Journal of Ethnobiology. 2008;28:69-91. doi:10.2993/0278-0771(2008)28[69:TUOBAM]2.0.CO;2.

52. Roberts TJ. The mammals of Pakistan. Oxford University Press; 1997.

53. Lavery TH. IUCN Red List of Threatened Species: Pteropus cognatus. IUCN Red List of Threatened Species. 2017. https://www.iucnredlist.org/species/136397/22014516. Accessed 31 Jan 2021.

54. Adeola MO. Importance of Wild Animals and Their Parts in the Culture, Religious Festivals, and Traditional Medicine, of Nigeria. Environ Conserv. 1992;19:125-34. doi:10.1017/S0376892900030605.

55. Vora NM, Osinubi M, Wallace RM, Aman-Oloniyo A, Gbadegesin YH, Sebastian YK, et al. Assessment of potential zoonotic disease exposure and illness related to an annual bat festival-Idanre, Nigeria. MMWR Morb Mortal Wkly Rep. 2014;63:334. https://www.ncbi.nlm.nih.gov/pubmed/24739343.

56. Wolfe ND, Eitel MN, Gockowski J, Muchaal PK, Nolte C, Tassy Prosser A, et al. Deforestation, hunting and the ecology of microbial emergence. Global Change and Human Health. 2000;1:10. doi:10.1023/A:1011519513354.

57. Peeters M, Courgnaud V, Abela B, Auzel P, Pourrut X, Bibollet-Ruche F, et al. Risk to human health from a plethora of simian immunodeficiency viruses in primate bushmeat. Emerg Infect Dis. 2002;8:4517. doi:10.3201/eid0805.010522.

58. Peeters M, D’Arc M, Delaporte E. Origin and diversity of human retroviruses. AIDS Rev. 2014;16:2334. https://www.ncbi.nlm.nih.gov/pubmed/24584106.

59. Sharp PM, Hahn BH. Origins of HIV and the AIDS pandemic. Cold Spring Harb Perspect Med. 2011;1:1-22. doi:10.1101/cshperspect.a006841.

60. Pepin J. The Origins of AIDS. Cambridge, UK ; New York: Cambridge University Press; 2011. http://www.amazon.com/The-Origins-AIDS-Jacques-Pepin/dp/0521186374.

61. Faria NR, Rambaut A, Suchard MA, Baele G, Bedford T, Ward MJ, et al. HIV epidemiology. The early spread and epidemic ignition of HIV-1 in human populations. Science. 2014;346:56-61. doi:10.1126/science. 1256739.

62. Hahn BH, Shaw GM, De Cock KM, Sharp PM. AIDS as a zoonosis: scientific and public health implications. Science. 2000;287:607-14. doi:10.1126/science.287.5453.607.

63. Chitnis A, Rawls D, Moore J. Origin of HIV type 1 in colonial French Equatorial Africa? AIDS Res Hum Retroviruses. 2000;16:5-8. doi:10.1089/088922200309548.

64. Leroy EM. Multiple Ebola virus transmission events and rapid decline of Central African wildlife. Science. 2004;303:387-90. doi:10.1126/science.1092528. 
65. Georges A-J, Leroy EM, Renaut AA, Benissan CT, Nabias RJ, Ngoc MT, et al. Ebola Hemorrhagic Fever Outbreaks in Gabon, 1994-1997: Epidemiologic and Health Control Issues. J Infect Dis. 1999;179 Supplement_1:S65-75. doi:10.1086/514290.

66. Leendertz FH, Ellerbrok H, Boesch C, Couacy-Hymann E, Mätz-Rensing K, Hakenbeck R, et al. Anthrax kills wild chimpanzees in a tropical rainforest. Nature. 2004;430:451-2. doi:10.1038/nature02722.

67. Mollentze N, Streicker DG. Viral zoonotic risk is homogenous among taxonomic orders of mammalian and avian reservoir hosts. Proc Natl Acad Sci U S A. 2020;117:9423-30. doi:10.1073/pnas.1919176117.

68. Cleaveland S, Laurenson MK, Taylor LH. Diseases of humans and their domestic mammals: pathogen characteristics, host range and the risk of emergence. Philos Trans R Soc Lond B Biol Sci. 2001;356:991-9. doi:10.1098/rstb.2001.0889.

69. Coffin JL, Monje F, Asiimwe-Karimu G, Amuguni HJ, Odoch T. A One Health, participatory epidemiology assessment of anthrax (Bacillus anthracis) management in Western Uganda. Soc Sci Med. 2015;129:44-50. doi:10.1016/j.socscimed.2014.07.037.

70. Rouquet P, Froment J-M, Bermejo M, Kilbourn A, Karesh W, Reed P, et al. Wild animal mortality monitoring and human Ebola outbreaks, Gabon and Republic of Congo, 2001-2003. Emerg Infect Dis. 2005;11:283-90. doi:10.3201/eid1102.040533.

71. Field H, Young P, Yob JM, Mills J, Hall L, Mackenzie J. The natural history of Hendra and Nipah viruses. Microbes Infect. 2001;3:307-14. doi:10.1016/S1286-4579(01)01384-3.

72. LeBreton M, Prosser AT, Tamoufe U, Sateren W, Mpoudi-Ngole E, Diffo JLD, et al. Patterns of bushmeat hunting and perceptions of disease risk among central African communities. Anim Conserv. 2006;9:357-63. doi:10.1111/j.1469-1795.2006.00030.x.

73. Sharp LA. Interspecies Engagement in Medical Anthropology. Med Anthropol Q. 2019;33:163-7. doi:10.1111/maq.12493.

74. Brown H, Nading AM. Introduction: Human Animal Health in Medical Anthropology. Med Anthropol Q. 2019;33:5-23. doi:10.1111/maq.12488.

75. Woldehanna S, Zimicki S. An expanded One Health model: Integrating social science and One Health to inform study of the human-animal interface. Soc Sci Med. 2015;129:87-95. doi:10.1016/j.socscimed.2014.10.059.

76. Friant S, Ayambem WA, Alobi AO, Ifebueme NM, Otukpa OM, Ogar DA, et al. Life on the Rainforest Edge: Food Security in the Agricultural-Forest Frontier of Cross River State, Nigeria. Frontiers in Sustainable Food Systems. 2019;3:113. doi:10.3389/fsufs.2019.00113.

77. Hofner AN, Jost Robinson CA, Nekaris KAI. Preserving Preuss's Red Colobus (Piliocolobus preussi): an Ethnographic Analysis of Hunting, Conservation, and Changing Perceptions of Primates in IkengeBakoko, Cameroon. Int J Primatol. 2018;39:895-917. doi:10.1007/s10764-018-0020-3.

78. Talbot PA. In the Shadow of the Bush. First Edition. William Heinemann, London; 1912. https://www.amazon.com/shadow-Bush-Percy-Amaury-Talbot/dp/B00085LEDY. 
79. Friant S, Ayambem WA, Alobi AO, Ifebueme NM, Otukpa OM, Ogar DA, et al. Eating Bushmeat Improves Food Security in a Biodiversity and Infectious Disease "Hotspot." Ecohealth. 2020. doi:10.1007/s10393-020-01473-0.

80. Kingdon J. The Kingdon pocket guide to African mammals. Princeton: Princeton University Press; 2005. http://www.amazon.com/Kingdon-Pocket-African-Mammals-Princeton/dp/0691122393.

81. Puri RK. Documenting local environmental knowledge and change. In: Newing $\mathrm{H}$, editor. Conducting Research in Conservation: A Social Science Perspective. New York: Routledge; 2011. p. 146-69.

82. Purzycki BG, Jamieson-Lane A. AnthroTools: An R Package for Cross-Cultural Ethnographic Data Analysis. Cross Cult Res. 2017;51:51-74. doi:10.1177/1069397116680352.

83. Whiting MJ, Williams VL, Hibbitts TJ. Animals traded for traditional medicine at the Faraday market in South Africa: species diversity and conservation implications: Conservation and traditional medicine. J Zool. 2011;284:84-96. doi:10.1111/j.1469-7998.2010.00784.x.

84. Vats R, Thomas S. A study on use of animals as traditional medicine by Sukuma Tribe of Busega District in North-western Tanzania. J Ethnobiol Ethnomed. 2015;11:38. doi:10.1186/s13002-0150001-y.

85. Dedeke GA, Ola M, Lawal OA, Soewu DA. Pilot survey of ethnozoological utilisation of vertebrates in southwestern Nigeria. Indilinga African Journal of Indigenous Knowledge Systems. 2006;5:87-96.

86. Ajagun JE, Anyaku EC. Conservation Status of Animal Species Used by Indigenous Traditional Medicine Practitioners in Ogbomoso, Oyo State. Journal of Complementary and Alternative Medical Research. 2017;:1-8. http://www.journaljocamr.com/index.php/JOCAMR/article/view/19629.

87. Sodeinde O, Soewu DA. Pilot Study of Traditional Medicine Trade in Nigeria with reference to wild fauna. TRAFFIC bulletin. 1999;18 1):35-40.

88. Soewu DA, Bakare OK, Ayodele IA. Trade in Wild Mammalian Species for Traditional Medicine in Ogun State, Nigeria. Global Journal of Medical Research. 2012;12.

89. Doty JB, Malekani JM, Kalemba LN, Stanley WT, Monroe BP, Nakazawa YU, et al. Assessing Monkeypox Virus Prevalence in Small Mammals at the Human-Animal Interface in the Democratic Republic of the Congo. Viruses. 2017;9:283. doi:10.3390/v9100283.

90. Ježek Z, Fenner F. Human monkeypox. In: Human monkeypox. S. Karger AG; 1988. https://www.cabdirect.org/cabdirect/abstract/19892057715. Accessed 22 Dec 2020.

91. Reynolds MG, Doty JB, McCollum AM, Olson VA, Nakazawa Y. Monkeypox re-emergence in Africa: a call to expand the concept and practice of One Health. Expert Rev Anti Infect Ther. 2019-2;17:12939. doi:10.1080/14787210.2019.1567330.

92. Yinka-Ogunleye A, Aruna O, Ogoina D, Aworabhi N, Eteng W, Badaru S, et al. Reemergence of Human Monkeypox in Nigeria, 2017. Emerg Infect Dis. 2018-6;24:1149-51. doi:10.3201/eid2406.180017.

93. Vorou R, Pierroutsakos IN, Maltezou HC. Crimean-Congo hemorrhagic fever. Curr Opin Infect Dis. 2007;20:495-500. doi:10.1097/QC0.0b013e3282a56a0a. 
94. Hoffmann C, Zimmermann F, Biek R, Kuehl H, Nowak K, Mundry R, et al. Persistent anthrax as a major driver of wildlife mortality in a tropical rainforest. Nature. 2017;548:82-6. doi:10.1038/nature23309.

95. Ogbeide O. Nutritional hazards of food taboos and preferences in Mid-West Nigeria. Am J Clin Nutr. 1974;27:213-6. doi:10.1093/ajcn/27.2.213.

96. Alade GO, Frank A, Kola'K A. Animals and animal products as medicines: A survey of Epie-Atissa and Ogbia people of Bayelsa State, Nigeria. Journal of Pharmacy \& Pharmacognosy Research. 2018;6:483-502.

97. Wolfe ND, Heneine W, Carr JK, Garcia AD, Shanmugam V, Tamoufe U, et al. Emergence of unique primate T-lymphotropic viruses among central African bushmeat hunters. Proceedings of the National Academy of Sciences. 2005;102:7994-7999.

http://www.pnas.org/content/102/22/7994.short. Accessed 24 Jun 2014.

98. Zheng H, Wolfe ND, Sintasath DM, Tamoufe U, LeBreton M, Djoko CF, et al. Emergence of a novel and highly divergent HTLV-3 in a primate hunter in Cameroon. Virology. 6/2010;401:137-45. doi:10.1016/j.virol.2010.03.010.

99. Wolfe ND, Prosser TA, Carr JK, Tamoufe U, Mpoudi-Ngole E, Torimiro JN, et al. Exposure to nonhuman primates in rural Cameroon. Emerg Infect Dis. 2004;10:2094-2099. http://wwwnc.cdc.gov/eid/article/10/12/04-0062.htm. Accessed 24 Jun 2014.

100. LeBreton M, Yang O, Tamoufe U, Mpoudi-Ngole E, Torimiro JN, Djoko CF, et al. Exposure to wild primates among HIV-infected persons. Emerg Infect Dis. 2007;13:1579.

http://www.ncbi.nlm.nih.gov/pmc/articles/PMC2851513/. Accessed 24 Jun 2014.

101. Nel LH, Rupprecht CE. Emergence of Lyssaviruses in the Old World: The Case of Africa. In: Childs JE, Mackenzie JS, Richt JA, editors. Wildlife and Emerging Zoonotic Diseases: The Biology, Circumstances and Consequences of Cross-Species Transmission. Berlin, Heidelberg: Springer Berlin Heidelberg; 2007. p. 161-93. doi:10.1007/978-3-540-70962-6_8.

102. Lelant V, Chenaval N. Note on a meeting with marabout from Fadial, Senegal, Western Africa, who uses bats in his medicine. Afr Bat Conserv News. 2012. https://www.semanticscholar.org/paper/888cae4999f22c58673b3480f39ce700fe83206a. Accessed 22 May 2020.

103. Jones KE, Patel NG, Levy MA, Storeygard A, Balk D, Gittleman JL, et al. Global trends in emerging infectious diseases. Nature. 2008;451:990-3. doi:10.1038/nature06536.

104. Johnson CK, Hitchens PL, Evans TS, Goldstein T, Thomas K, Clements A, et al. Spillover and pandemic properties of zoonotic viruses with high host plasticity. Sci Rep. 2015;5:14830. doi:10.1038/srep14830.

105. Mathias E, Mccorkle CM. Traditional livestock healers. Rev sci tech Off int Epiz. 2004;23:277-84. doi:10.20506/rst.23.1.1474.

106. Soewu DA, Ayodele IA. Utilisation of Pangolin (Manis sps) in traditional Yorubic medicine in ljebu province, Ogun State, Nigeria. J Ethnobiol Ethnomed. 2009;5:39. doi:10.1186/1746-4269-5-39. 
107. Soewu DA, Adekanola TA. Traditional-medical knowledge and perception of pangolins (Manis sps) among the Awori people, Southwestern Nigeria. J Ethnobiol Ethnomed. 2011;7:25. doi:10.1186/17464269-7-25.

108. Boakye MK, Pietersen DW, Kotzé A, Dalton D-L, Jansen R. Knowledge and uses of African pangolins as a source of traditional medicine in Ghana. PLoS One. 2015;10:e0117199. doi:10.1371/journal.pone.0117199.

109. Setlalekgomo MR. Ethnozoological survey of the indigenous knowledge on the use of pangolins (Manis sps.) in traditional medicine in Lentsweletau Extended Area in Botswana. Journal of Animal Science Advances. 2014;4:883-90.

110. Xu L, Guan J, Lau W, Xiao Y. An Overview of Pangolin Trade in China. TRAFFIC briefing. 2016.

111. Lam TT-Y, Shum MH-H, Zhu H-C, Tong Y-G, Ni X-B, Liao Y-S, et al. Identifying SARS-CoV-2 related coronaviruses in Malayan pangolins. Nature. 2020. doi:10.1038/s41586-020-2169-0.

112. Heinrich S, Wittman TA, Ross JV, Shepherd CR, Challender DWS, Cassey P. The global trafficking of pangolins: A comprehensive summary of seizures and trafficking routes from 2010-2015. TRAFFIC; 2017. https://www.traffic.org/site/assets/files/1606/global-pangolin-assessment.pdf.

113. Sofowora A. Research on medicinal plants and traditional medicine in Africa. J Altern Complement Med. 1996;2:365-72. doi:10.1089/acm.1996.2.365.

114. Stephens PR, Pappalardo P, Huang S, Byers JE, Farrell MJ, Gehman A, et al. Global Mammal Parasite Database version 2.0. Ecology. 2017;98:1476. doi:10.1002/ecy.1799.

115. Wang Y, Tu X, Humphrey C, McClure H, Jiang X, Qin C, et al. Detection of viral agents in fecal specimens of monkeys with diarrhea. J Med Primatol. 2007;36:101-7. doi:10.1111/j.16000684.2006.00167.x.

116. Centers for Disease Control and Prevention (CDC). Inhalation anthrax associated with dried animal hides--Pennsylvania and New York City, 2006. MMWR Morb Mortal Wkly Rep. 2006;55:280-2. https://www.ncbi.nlm.nih.gov/pubmed/16543883.

117. McCollum AM, Li Y, Wilkins K, Karem KL, Davidson WB, Paddock CD, et al. Poxvirus viability and signatures in historical relics. Emerg Infect Dis. 2014;20:177-84. doi:10.3201/eid2002/131098.

118. Espinosa MF, Sancho AN, Mendoza LM, Mota CR, Verbyla ME. Systematic review and meta-analysis of time-temperature pathogen inactivation. Int J Hyg Environ Health. 2020;230:113595. doi:10.1016/j.ijheh.2020.113595.

119. Boyce JM, Pittet D, Healthcare Infection Control Practices Advisory Committee, HICPAC/SHEA/APIC/IDSA Hand Hygiene Task Force. Guideline for Hand Hygiene in Health-Care Settings. Recommendations of the Healthcare Infection Control Practices Advisory Committee and the HICPAC/SHEA/APIC/IDSA Hand Hygiene Task Force. Society for Healthcare Epidemiology of America/Association for Professionals in Infection Control/Infectious Diseases Society of America. MMWR Recomm Rep. 2002;51 RR-16:1-45, quiz CE1-4. https://www.ncbi.nlm.nih.gov/pubmed/12418624. 
120. Idonije OB, Festus OO, llegbusi MI, Okhiai O. A Comparative Biochemical Analysis of Local Gin (Ogogoro) from Different Parts of Nigeria and Imported Gin (Dry Gin) - Toxicogenic, Carcinogenic and Sociopolitical Implications. Science Journal of Medicine and Clinical Trials. 2012. doi:10.7237/sjmct/179.

121. Types of Anthrax. 2020. https://www.cdc.gov/anthrax/basics/types/index.html. Accessed 15 Apr 2021.

122. Airborne Transmission. 2019. https://www.cdc.gov/hantavirus/technical/hanta/airbornetransmission.html. Accessed 15 Apr 2021.

123. Arenaviridae. 2019. https://www.cdc.gov/vhf/virus-families/arenaviridae.html. Accessed $15 \mathrm{Apr}$ 2021.

124. Namusisi S, Mahero M, Travis D, Pelican K, Robertson C, Mugisha L. A descriptive study of zoonotic disease risk at the human-wildlife interface in a biodiversity hot spot in South Western Uganda. PLoS Negl Trop Dis. 2021;15:e0008633. doi:10.1371/journal.pntd.0008633.

125. Last M. The importance of knowing about not knowing. Soc Sci Med B. 1981;15:387-92. doi:10.1016/0160-7987(81)90064-8.

126. Abayomi F, Dedeke GA. Ethnozoological trade and practices among the ljebu people of south-western Nigeria and the impact on some mammalian species. Indilinga African Journal of Indigenous Knowledge Systems. 2006;5:175-87. https://journals.co.za/content/linga/5/2/EJC61508.

127. Ogoanah OS, Omijie F. Animal Species Used for Traditional Medicine in Benin City, Nigeria. NISEB Journal. 2019;17. http://ojs.klobexjournals.com/index.php/nisebj/article/view/255/0. Accessed 29 Jul 2020.

128. Saidu Y, Buij R. Traditional medicine trade in vulture parts in northern Nigeria. 1. 2013;65:4-14. doi:10.4314/vulnew.v65i1.1.

129. Luiselli L, Petrozzi F, Akani GC. Long-term comparison reveals trends in turtle trade in bushmeat markets of southern Nigeria. Herpetozoa. 2013;26:57-64. https://www.zobodat.at/pdf/HER_26_1_2_0057-0064.pdf.

130. Svensson M, Friant S. Threats from trading and hunting of pottos and angwantibos in Africa resemble those faced by slow lorises in Asia. Endanger Species Res. 2014;23:107-14. doi:10.3354/esr00572.

131. Izugbara CO, Etukudoh IW, Brown AS. Transethnic itineraries for ethnomedical therapies in Nigeria: Igbo women seeking Ibibio cures. Health Place. 2005;11:1-14. doi:10.1016/j.healthplace.2003.12.001.

132. Alves RRN, Medeiros MFT, Albuquerque UP, Rosa IL. From Past to Present: Medicinal Animals in a Historical Perspective. In: Alves RRN, Rosa IL, editors. Animals in Traditional Folk Medicine: Implications for Conservation. Berlin, Heidelberg: Springer Berlin Heidelberg; 2013. p. 11-23. doi:10.1007/978-3-642-29026-8_2.

133. Alves RRN, Rosa IL. Trade of Animals Used in Brazilian Traditional Medicine: Trends and Implications for Conservation. Hum Ecol. 2010;38:691-704. doi:10.1007/s10745-010-9352-0. 
134. Alves RRN, Rosa IL. From cnidarians to mammals: the use of animals as remedies in fishing communities in NE Brazil. J Ethnopharmacol. 2006;107:259-76. doi:10.1016/j.jep.2006.03.007.

135. Sanderson IT. Animal Treasure. First edition. Viking Adult; 1937.

136. Friant S, Brown K, Saari MT, Segel NH, Slezak J, Goldberg TL. Lung fluke (Paragonimus africanus) infects Nigerian red-capped mangabeys and causes respiratory disease. Int J Parasitol Parasites Wildl. 2015;4:329-32. doi:10.1016/j.ijppaw.2015.08.003.

137. Subramanian M. Zoonotic disease risk and the bushmeat trade: assessing awareness among hunters and traders in Sierra Leone. Ecohealth. 2012;9:471-82. doi:10.1007/s10393-012-0807-1.

138. Rupp S, Ambata P, Narat V, Giles-Vernick T. Beyond the Cut Hunter: A Historical Epidemiology of HIV Beginnings in Central Africa. Ecohealth. 2016;:1-11. doi:10.1007/s10393-016-1189-6.

139. Brown D, Williams A. The case for bushmeat as a component of development policy: issues and challenges. Int For Rev. 2003;5:148-155. http://www.ingentaconnect.com/content/cfa/ifr/2003/00000005/00000002/art00008. Accessed 23 Jun 2014.

\section{Figures}




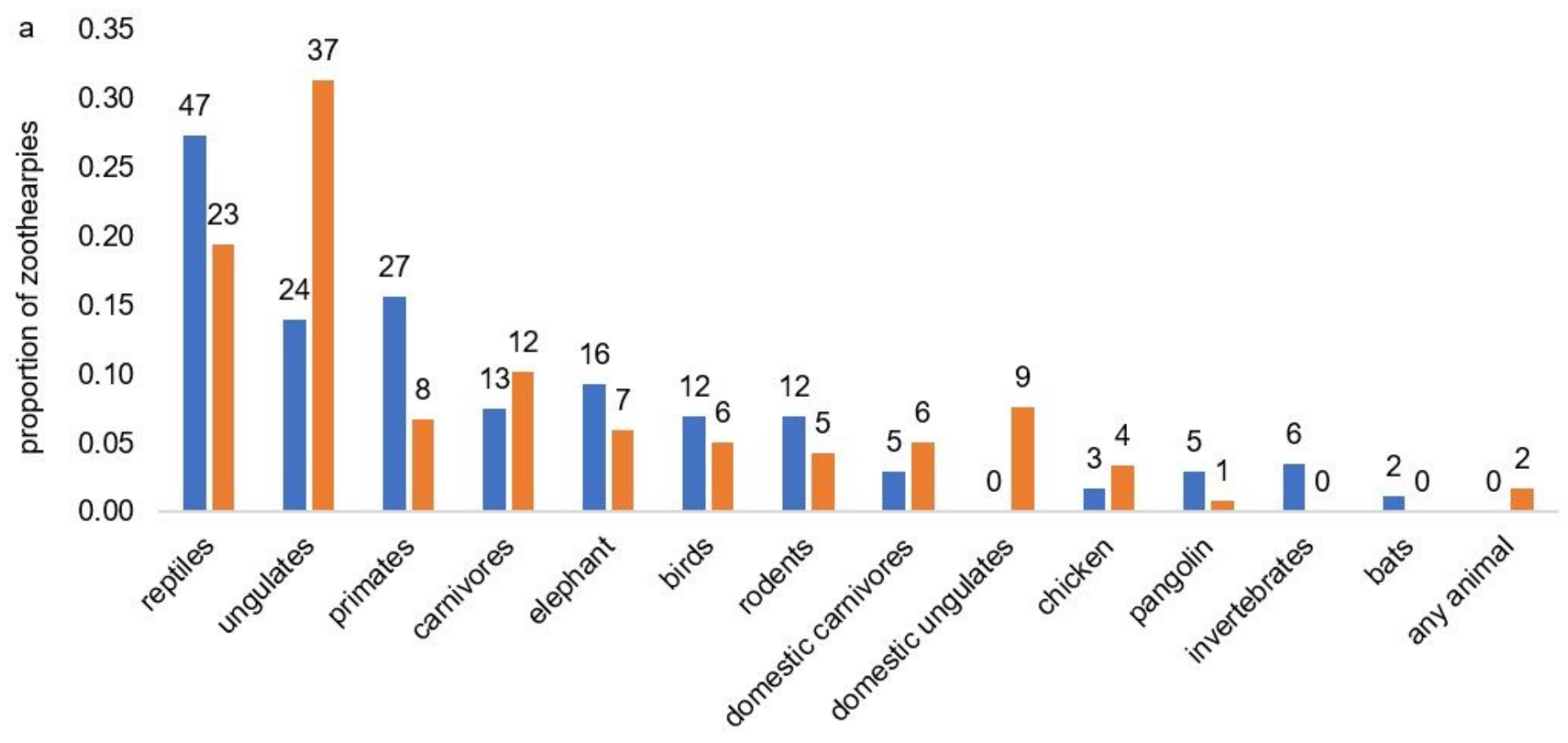

b $\quad 0.35$

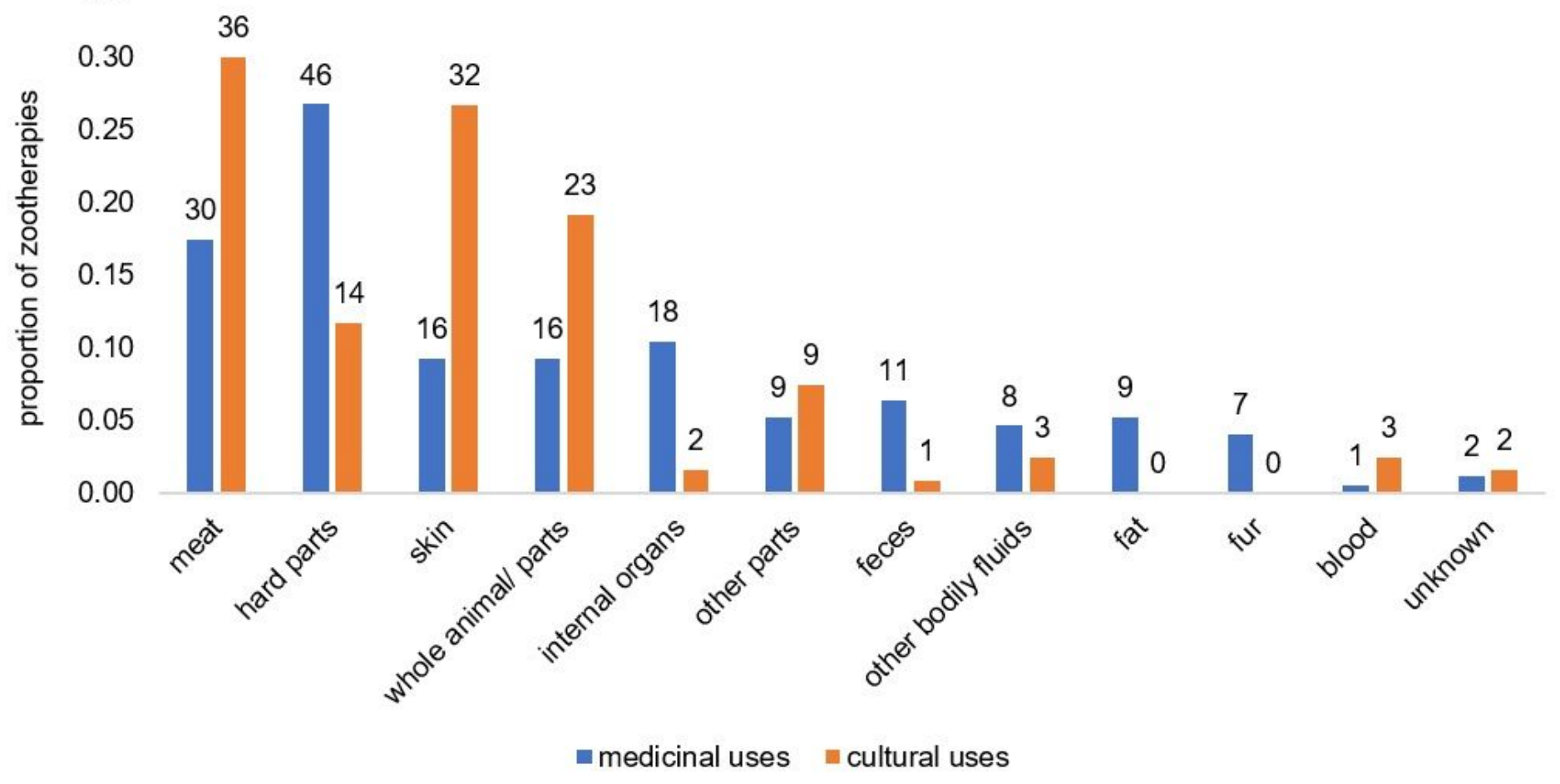

Figure 1

Proportion of described zootherapies, including medicinal (blue; $\mathrm{N}=172$ ) and cultural (orange; $\mathrm{N}=120$ ) practices, involving different species (a) and parts of the body (b). 
a ) medicinal use

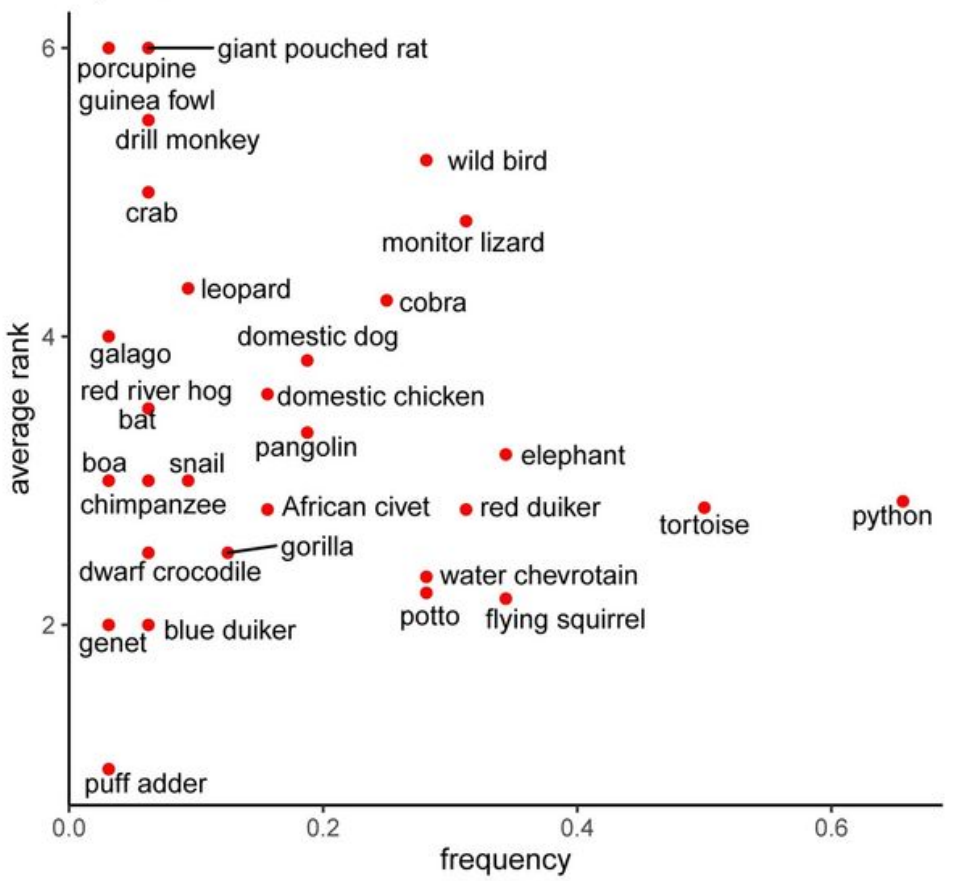

b ) other cultural uses

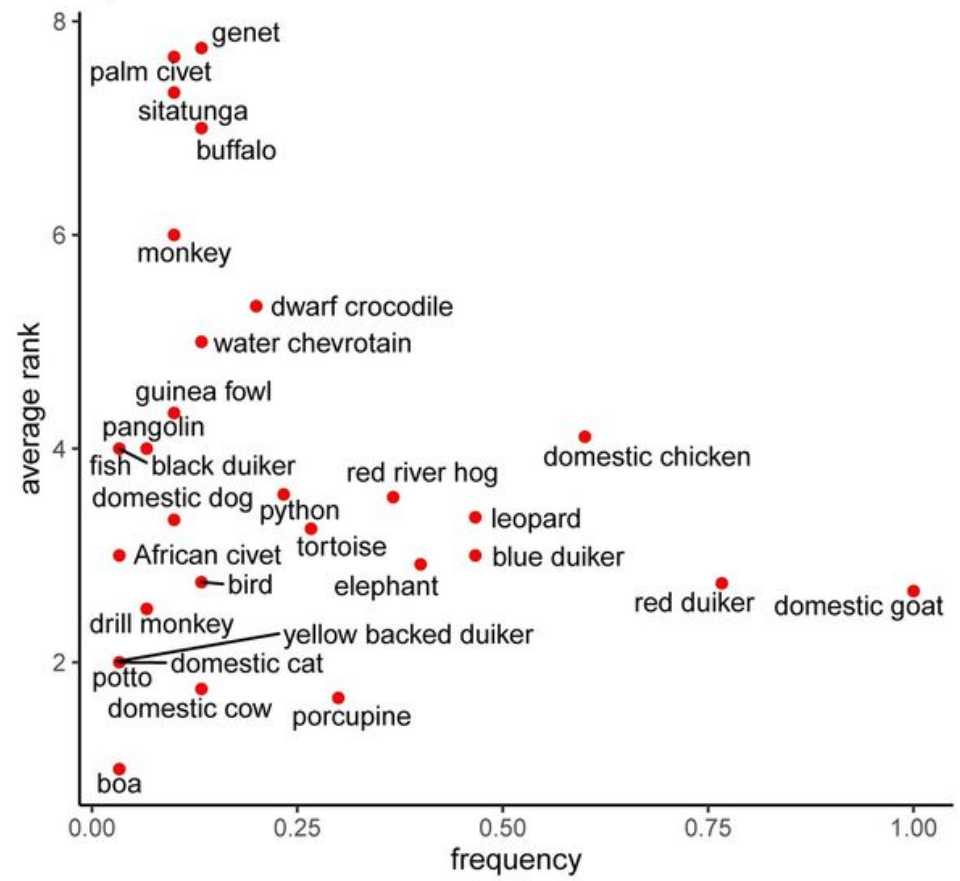

\section{Figure 2}

Salience of animals used for medicine (a) and other cultural purposes (b). Plots show the frequency an animal was mentioned ( $x$-axis) and the average rank assigned to each animal ( $y$-axis) during free listing exercises with key informants $(n=50)$. The most salient animals are shown in the lower right-hand quadrant, indicating they were frequently listed and assigned a high average rank ( 1 =high rank).
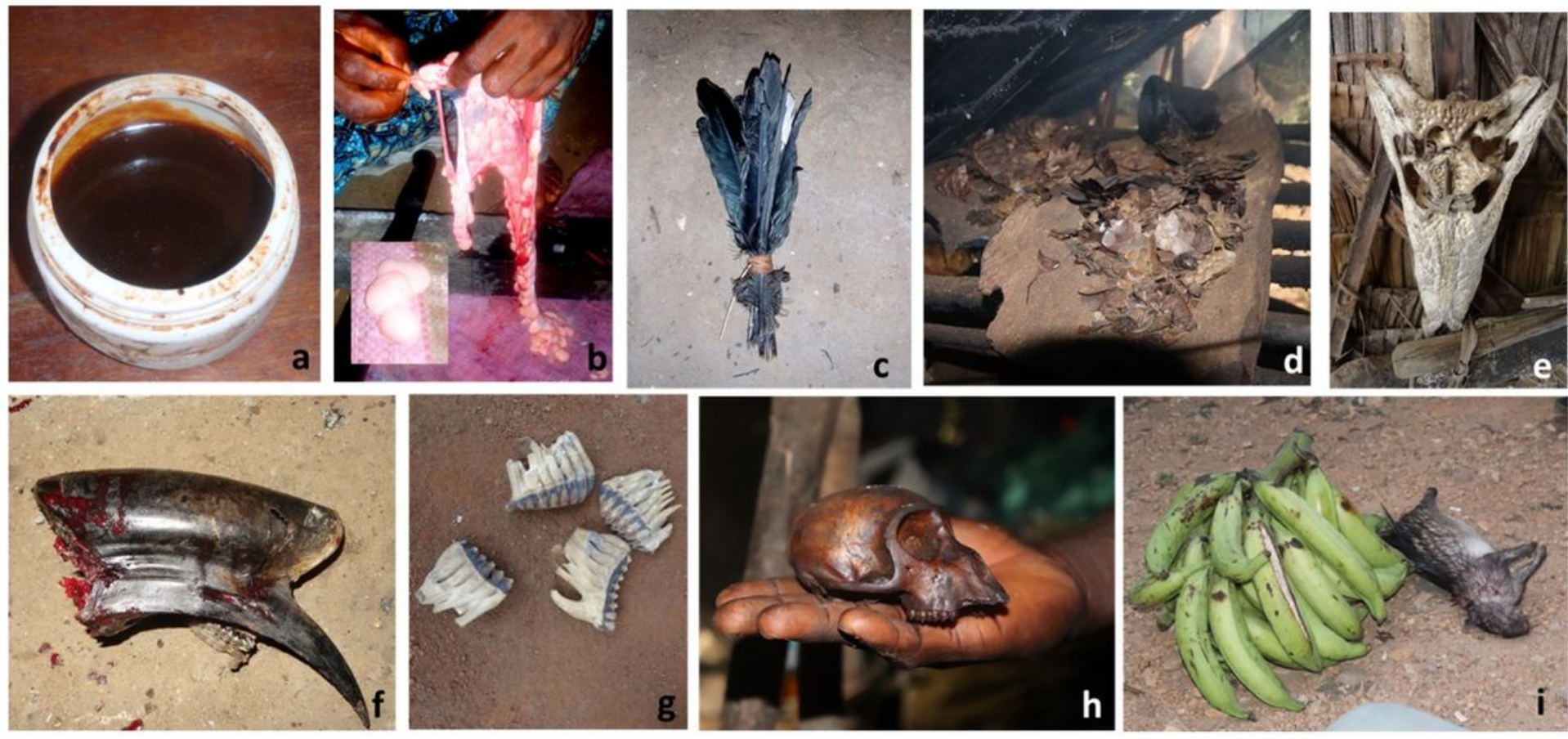

\section{Figure 3}


Images of animal parts used as zootherapy: python oil made from fat and stored for use as body rub (a); fresh python fat mixed with local liquor or dried and used as lozenges (b); wild bird feathers for various cultural practices and decorations (c); pangolin scales being reduced to ashes for consumption to cure various illnesses (d); skull of dwarf crocodile hung in town hall for use during cultural festivities and/or charms (e); hornbill beak (f) and elephant teeth ( $\mathrm{g}$ ) traded for unknown medicinal use; monkey skull used as a vessel to prepare and administer medicine $(h)$; and whole raw porcupine gifted to visitors with plantain to welcome them and bring good luck (i).

\section{Supplementary Files}

This is a list of supplementary files associated with this preprint. Click to download.

- AdditionalFile1.Searchstrategy.docx

- AdditionalFile2.MedicinalandCulturalUses.docx

- AdditionalFile3.QuantitativeData.csv 